Review

\title{
Sulfur and Water Resistance of Mn-Based Catalysts for Low-Temperature Selective Catalytic Reduction of $\mathrm{NO}_{\mathbf{x}}$ : A Review
}

\author{
Chen Gao, Jian-Wen Shi * (1), Zhaoyang Fan, Ge Gao and Chunming Niu * \\ Center of Nanomaterials for Renewable Energy, State Key Laboratory of Electrical Insulation and Power \\ Equipment, School of Electrical Engineering, Xi'an Jiaotong University, Xi'an 710049, China; \\ rick.gcgc@stu.xjtu.edu.cn (C.G.); z.y.fan@stu.xjtu.edu.cn (Z.F.); gaoge5022@stu.xjtu.edu.cn (G.G.) \\ * Correspondence: jianwen.shi@mail.xjtu.edu.cn (J.-W.S.); cniu@mail.xjtu.edu.cn (C.N.)
}

Received: 6 December 2017; Accepted: 3 January 2018; Published: 7 January 2018

\begin{abstract}
Selective catalytic reduction (SCR) with $\mathrm{NH}_{3}$ is the most efficient and economic flue gas denitrification technology developed to date. Due to its high low-temperature catalytic activity, Mn-based catalysts present a great prospect for application in SCR de- $\mathrm{NO}_{x}$ at low temperatures. However, overcoming the poor resistance of Mn-based catalysts to $\mathrm{H}_{2} \mathrm{O}$ and $\mathrm{SO}_{2}$ poison is still a challenge. This paper reviews the recent progress on the $\mathrm{H}_{2} \mathrm{O}$ and $\mathrm{SO}_{2}$ resistance of $\mathrm{Mn}$-based catalysts for the low-temperature SCR of $\mathrm{NO}_{x}$. Firstly, the poison mechanisms of $\mathrm{H}_{2} \mathrm{O}$ and $\mathrm{SO}_{2}$ are introduced in detail, respectively. Secondly, Mn-based catalysts are divided into three categories - single $\mathrm{MnO}_{\mathrm{x}}$ catalysts, Mn-based multi-metal oxide catalysts, and Mn-based supported catalysts-to review the research progress of Mn-based catalysts for $\mathrm{H}_{2} \mathrm{O}$ and $\mathrm{SO}_{2}$ resistance. Thirdly, several strategies to reduce the poisonous effects of $\mathrm{H}_{2} \mathrm{O}$ and $\mathrm{SO}_{2}$, such as metal modification, proper support, the combination of metal modification and support, the rational design of structure and morphology, are summarized. Finally, perspectives and future directions of Mn-based catalysts for the low-temperature $\mathrm{SCR}$ of $\mathrm{NO}_{\mathrm{x}}$ are proposed.
\end{abstract}

Keywords: selective catalytic reduction; Mn-based catalysts; $\mathrm{H}_{2} \mathrm{O}$ and $\mathrm{SO}_{2}$ resistance; low-temperature; de- $\mathrm{NO}_{\mathrm{x}}$

\section{Introduction}

Nitrogen oxides $\left(\mathrm{NO}_{\mathrm{x}}, \mathrm{x}=1,2\right)$ emitted from power plants and diesel engines are major air pollutants that can cause acid rain, photochemical smog, ozone depletion, and other severe environmental problems [1-5]. Selective catalytic reduction (SCR) with $\mathrm{NH}_{3}$ is the most efficient and economic method for post- $\mathrm{NO}_{\mathrm{x}}$ abatement, and $\mathrm{V}_{2} \mathrm{O}_{5}-\mathrm{WO}_{3}\left(\mathrm{MoO}_{3}\right) / \mathrm{TiO}_{2}$ has been the most popular commercial SCR catalyst since the 1970s [6,7]. However, $\mathrm{V}_{2} \mathrm{O}_{5}$-based catalysts have drawbacks, such as the toxicity of vanadium, $\mathrm{SO}_{2}$ oxidation to $\mathrm{SO}_{3}$, over-oxidation of $\mathrm{NH}_{3}$ to $\mathrm{N}_{2} \mathrm{O}$, and a high working temperature [8]. Because of the high working temperature window $\left(300-400{ }^{\circ} \mathrm{C}\right), \mathrm{V}_{2} \mathrm{O}_{5}$-based catalysts have to be placed upstream of the dust removal system and desulfurization units to avoid costly heating of the flue gas, where the catalysts are susceptible to deactivation by dust accumulation and $\mathrm{SO}_{2}$ poison. Therefore, $\mathrm{SCR}$ catalysts that are environmentally friendly and can work at low temperatures (around $250^{\circ} \mathrm{C}$ or even lower) urgently need to be developed [9-11].

Due to its high low-temperature catalytic activity, manganese oxide $\left(\mathrm{MnO}_{\mathrm{x}}\right)$ has been intensively studied in recent decades [4,12-14]. Recently, our research group has also made a series of progress in the low-temperature SCR of $\mathrm{NO}$ with $\mathrm{NH}_{3}$ over Mn-based catalysts [15-21]. However, several problems, including thermal instability, narrow operation window, and poor resistance to $\mathrm{H}_{2} \mathrm{O}$ and $\mathrm{SO}_{2}$ poison, remain. Among these drawbacks, the poor tolerance to $\mathrm{H}_{2} \mathrm{O}$ and 
$\mathrm{SO}_{2}$ is one of the most significant disadvantages, which limits the practical application of Mn-based catalysts [22]. Researchers have done numerous studies to develop Mn-based catalysts with good tolerance to water and sulfur and to uncover the deactivation mechanism of Mn-based catalysts in the presence of water and sulfur. In this review, we focused on the recent progress on the water and sulfur resistance of Mn-based catalysts. To make the organization clear, catalysts were introduced by the following three categories, single $\mathrm{MnO}_{\mathrm{x}}$ catalysts, $\mathrm{Mn}$-based multi-metal oxide catalysts and Mn-based supported catalysts. Table 1 summarizes Mn-based catalysts reported in the literature that have exhibited good performance in the presence of water and sulfur. 
Table 1. Summary of the current status of $\mathrm{H}_{2} \mathrm{O}$ and $\mathrm{SO}_{2}$ tolerance study on $\mathrm{Mn}$-based catalysts in the literature.

\begin{tabular}{|c|c|c|c|c|c|c|}
\hline Catalyst & Reaction Conditions & $\mathrm{T} /{ }^{\circ} \mathrm{C}$ & $\mathrm{X}_{\mathrm{NO}}$ & $\mathrm{X}_{\mathrm{NO}}-\mathrm{U}$ & $\mathrm{X}_{\mathrm{NO}}-\mathrm{A}$ & References \\
\hline $\mathrm{MnO}_{\mathrm{x}}$ & $500 \mathrm{ppm} \mathrm{NH}_{3}, 500 \mathrm{ppm} \mathrm{NO}, 3 \% \mathrm{O}_{2}, 10 \% \mathrm{H}_{2} \mathrm{O}, 100 \mathrm{ppm} \mathrm{SO}_{2} \mathrm{GHSV}_{\text {at }} 47,000 \mathrm{~h}^{-1}$ & 80 & $98 \%$ & $70 \%$ & $90 \%$ & [13] \\
\hline $\mathrm{MnO}_{\mathrm{x}}$ & $500 \mathrm{ppm} \mathrm{NH}_{3}, 500 \mathrm{ppm} \mathrm{NO}, 5 \% \mathrm{O}_{2}, 11 \% \mathrm{H}_{2} \mathrm{O}, 100 \mathrm{ppm} \mathrm{SO}_{2} \mathrm{GHSV}$ at $50,000 \mathrm{~h}^{-1}$ & 120 & $100 \%$ & $94 \%$ & $100 \%$ & [23] \\
\hline $\mathrm{Mn}-\mathrm{Ce}$ & $1000 \mathrm{ppm} \mathrm{NH}_{3}, 1000 \mathrm{ppm} \mathrm{NO}, 2 \% \mathrm{O}_{2}, 2.5 \% \mathrm{H}_{2} \mathrm{O}, 100 \mathrm{ppm} \mathrm{SO}{ }_{2} \mathrm{GHSV}$ at $42,000 \mathrm{~h}^{-1}$ & 120 & $100 \%$ & $95 \%$ & $100 \%$ & [24] \\
\hline $\mathrm{Mn}-\mathrm{Ce}$ & $500 \mathrm{ppm} \mathrm{NH}{ }_{3}, 500 \mathrm{ppm} \mathrm{NO}, 5 \% \mathrm{O}_{2}, 5 \% \mathrm{H}_{2} \mathrm{O}, 50 \mathrm{ppm} \mathrm{SO}_{2} \mathrm{GHSV}$ at $64,000 \mathrm{~h}^{-1}$ & 150 & $\sim 98 \%$ & $\sim 95 \%$ & / & [25] \\
\hline $\mathrm{Mn}-\mathrm{Ce}$ & $500 \mathrm{ppm} \mathrm{NH}_{3}, 500 \mathrm{ppm} \mathrm{NO}, 5 \% \mathrm{O}_{2}, 5 \% \mathrm{H}_{2} \mathrm{O}, 100 \mathrm{ppm} \mathrm{SO}_{2} 60,000 \mathrm{~mL} \mathrm{~g}^{-1} \mathrm{~h}^{-1}$ & 200 & $\sim 97 \%$ & $\sim 70 \%$ & $\sim 85 \%$ & [26] \\
\hline $\mathrm{Mn}-\mathrm{Fe}$ & $1000 \mathrm{ppm} \mathrm{NH}_{3}, 1000 \mathrm{ppm} \mathrm{NO}, 2 \% \mathrm{O}_{2}, 2.5 \% \mathrm{H}_{2} \mathrm{O}, 37.5 \mathrm{ppm} \mathrm{SO}_{2} \mathrm{GHSV}$ at $15,000 \mathrm{~h}^{-1}$ & 160 & $100 \%$ & $\sim 98 \%$ & / & [27] \\
\hline $\mathrm{Mn}-\mathrm{Fe}$ & $1000 \mathrm{ppm} \mathrm{NH} \mathrm{N}_{3}, 1000 \mathrm{ppm} \mathrm{NO}, 3 \% \mathrm{O}_{2}, 5 \% \mathrm{H}_{2} \mathrm{O}, 100 \mathrm{ppm} \mathrm{SO}_{2} \mathrm{GHSV}$ at $30,000 \mathrm{~h}^{-1}$ & 120 & $100 \%$ & $87 \%$ & $93 \%$ & [28] \\
\hline $\mathrm{Mn}-\mathrm{Co}$ & $500 \mathrm{ppm} \mathrm{NH} \mathrm{NH}_{3}, 500 \mathrm{ppm} \mathrm{NO}, 3 \% \mathrm{O}_{2}, 8 \% \mathrm{H}_{2} \mathrm{O}, 200 \mathrm{ppm} \mathrm{SO}_{2} \mathrm{GHSV}$ at $38,000 \mathrm{~h}^{-1}$ & 175 & $100 \%$ & $90 \%$ & $100 \%$ & [29] \\
\hline $\mathrm{Mn}-\mathrm{Co}$ & 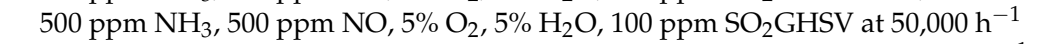 & 200 & $100 \%$ & $80 \%$ & $90 \%$ & {$[30,31]$} \\
\hline $\mathrm{Mn}-\mathrm{Cu}$ & $500 \mathrm{ppm} \mathrm{NH}_{3}, 500 \mathrm{ppm} \mathrm{NO}, 5 \% \mathrm{O}_{2}, 11 \% \mathrm{H}_{2} \mathrm{O}, 100 \mathrm{ppm} \mathrm{SO}_{2} \mathrm{GHSV}$ at $50,000 \mathrm{~h}^{-1}$ & 125 & $95 \%$ & $64 \%$ & $\sim 90 \%$ & {$[32]$} \\
\hline $\mathrm{Mn}-\mathrm{Sm}$ & $500 \mathrm{ppm} \mathrm{NH}_{3}, 500 \mathrm{ppm} \mathrm{NO}, 5 \% \mathrm{O}_{2}, 2 \% \mathrm{H}_{2} \mathrm{O}, 100 \mathrm{ppm} \mathrm{SO}_{2} \mathrm{GHSV}$ at $49,000 \mathrm{~h}^{-1}$ & 100 & $100 \%$ & $91 \%$ & $97 \%$ & [33] \\
\hline $\mathrm{Mn}-\mathrm{Eu}$ & $600 \mathrm{ppm} \mathrm{NH}_{3}, 600 \mathrm{ppm} \mathrm{NO}, 5 \% \mathrm{O}_{2}, 5 \% \mathrm{H}_{2} \mathrm{O}, 100 \mathrm{ppm} \mathrm{SO}_{2} \mathrm{GHSV}$ at $108,000 \mathrm{~h}^{-1}$ & 350 & $100 \%$ & $90 \%$ & $95 \%$ & [34] \\
\hline $\mathrm{Mn}-\mathrm{Fe}-\mathrm{Ce}$ & $1000 \mathrm{ppm} \mathrm{NH}_{3}, 1000 \mathrm{ppm} \mathrm{NO}, 2 \% \mathrm{O}_{2}, 2.5 \% \mathrm{H}_{2} \mathrm{O}, 100 \mathrm{ppm} \mathrm{SO}_{2} \mathrm{GHSV}$ at $42,000 \mathrm{~h}^{-1}$ & 150 & $98 \%$ & $95 \%$ & $98 \%$ & [35] \\
\hline $\mathrm{Mn}-\mathrm{Ce}-\mathrm{Fe}$ & $1000 \mathrm{ppm} \mathrm{NH}_{3}, 1000 \mathrm{ppm} \mathrm{NO}, 3 \% \mathrm{O}_{2}, 10 \% \mathrm{H}_{2} \mathrm{O}, 100 \mathrm{ppm} \mathrm{SO}_{2} \mathrm{GHSV}$ at $30,000 \mathrm{~h}^{-1}$ & 120 & $100 \%$ & $75 \%$ & $95 \%$ & [36] \\
\hline $\mathrm{Mn}-\mathrm{Sn}-\mathrm{Ce}$ & $1000 \mathrm{ppm} \mathrm{NH}{ }_{3}, 1000 \mathrm{ppm} \mathrm{NO}, 2 \% \mathrm{O}_{2}, 12 \% \mathrm{H}_{2} \mathrm{O}, 100 \mathrm{ppm} \mathrm{SO} \mathrm{GHSV}_{2} 35,000 \mathrm{~h}^{-1}$ & 110 & $100 \%$ & $70 \%$ & $90 \%$ & {$[37,38]$} \\
\hline $\mathrm{Mn}-\mathrm{Ce}-\mathrm{Ni}$ & $500 \mathrm{ppm} \mathrm{NH}_{3}, 500 \mathrm{ppm} \mathrm{NO}, 5 \% \mathrm{O}_{2}, 10 \% \mathrm{H}_{2} \mathrm{O}, 150 \mathrm{ppm} \mathrm{SO}_{2} \mathrm{GHSV}$ at $48,000 \mathrm{~h}^{-1}$ & 175 & $\sim 90 \%$ & $\sim 78 \%$ & $\sim 90 \%$ & [39] \\
\hline $\mathrm{Mn}-\mathrm{Ce}-\mathrm{Co}$ & $500 \mathrm{ppm} \mathrm{NH}{ }_{3}, 500 \mathrm{ppm} \mathrm{NO}, 5 \% \mathrm{O}_{2}, 10 \% \mathrm{H}_{2} \mathrm{O}, 150 \mathrm{ppm} \mathrm{SO}_{2} \mathrm{GHSV}$ at $48,000 \mathrm{~h}^{-1}$ & 175 & $\sim 90 \%$ & $\sim 72 \%$ & $\sim 90 \%$ & [39] \\
\hline $\mathrm{Mn}-\mathrm{W}-\mathrm{Zr}$ & $500 \mathrm{ppm} \mathrm{NH} 3,500 \mathrm{ppm} \mathrm{NO} 5 \% \mathrm{O}_{2}, 5 \% \mathrm{H}_{2} \mathrm{O}, 50 \mathrm{ppm} \mathrm{SO}{ }_{2} \mathrm{GHSV}$ at $128,000 \mathrm{~h}^{-1}$ & 300 & $100 \%$ & $\sim 90 \%$ & $100 \%$ & [40] \\
\hline $\mathrm{Mn}-\mathrm{Fe} / \mathrm{TiO}_{2}$ & $1000 \mathrm{ppm} \mathrm{NH}_{3}, 1000 \mathrm{ppm} \mathrm{NO}, 2 \% \mathrm{O}_{2}, 2.5 \% \mathrm{H}_{2} \mathrm{O}, 100 \mathrm{ppm} \mathrm{SO}_{2} \mathrm{GHSV}$ at $15,000 \mathrm{~h}^{-1}$ & 150 & $100 \%$ & $90 \%$ & $100 \%$ & [41] \\
\hline $\mathrm{Mn} / \mathrm{Fe}-\mathrm{TiO}_{2}$ & $500 \mathrm{ppm} \mathrm{NH}_{3}, 500 \mathrm{ppm} \mathrm{NO}, 2 \% \mathrm{O}_{2}, 8 \% \mathrm{H}_{2} \mathrm{O}, 60 \mathrm{ppm} \mathrm{SO}_{2} \mathrm{GHSV}$ at $12,000 \mathrm{~h}^{-1}$ & 200 & $100 \%$ & $83 \%$ & $100 \%$ & [42] \\
\hline $\mathrm{Mn}-\mathrm{Ce} / \mathrm{TiO}_{2}$ & $1000 \mathrm{ppm} \mathrm{NH}_{3}, 1000 \mathrm{ppm} \mathrm{NO}, 3 \% \mathrm{O}_{2}, 3 \% \mathrm{H}_{2} \mathrm{O}, 100 \mathrm{ppm} \mathrm{SO}_{2} \mathrm{GHSV}$ at $30,000 \mathrm{~h}^{-1}$ & 150 & $100 \%$ & $84 \%$ & / & [9] \\
\hline $\mathrm{Mn}-\mathrm{Fe}-\mathrm{Ce} / \mathrm{TiO}_{2}$ & $600 \mathrm{ppm} \mathrm{NH} \mathrm{NH}_{3}, 600 \mathrm{ppm} \mathrm{NO}, 3 \% \mathrm{O}_{2}, 3 \% \mathrm{H}_{2} \mathrm{O}, 100 \mathrm{ppm} \mathrm{SO}_{2} \mathrm{GHSV}$ at $50,000 \mathrm{~h}^{-1}$ & 180 & $100 \%$ & $84 \%$ & $90 \%$ & [43] \\
\hline $\mathrm{Mn}-\mathrm{Ce} / \mathrm{Ti}-\mathrm{PILC}$ & $600 \mathrm{ppm} \mathrm{NH}_{3}, 600 \mathrm{ppm} \mathrm{NO}, 3 \% \mathrm{O}_{2}, 3 \% \mathrm{H}_{2} \mathrm{O}, 100 \mathrm{ppm} \mathrm{SO}_{2} \mathrm{GHSV}$ at $50,000 \mathrm{~h}^{-1}$ & 200 & $\sim 95 \%$ & $\sim 90 \%$ & $\sim 90 \%$ & [44] \\
\hline $\mathrm{Mn}-\mathrm{Ce} / \mathrm{TiO}_{2}$ & $220 \mathrm{ppm} \mathrm{NH}_{3}, 200 \mathrm{ppm} \mathrm{NO}, 8 \% \mathrm{O}_{2}, 6 \% \mathrm{H}_{2} \mathrm{O}, 100 \mathrm{ppm} \mathrm{SO}_{2} \mathrm{GHSV}$ at $60,000 \mathrm{~h}^{-1}$ & 180 & $100 \%$ & $62 \%$ & $70 \%$ & [45] \\
\hline $\mathrm{Mn}-\mathrm{Ce} / \mathrm{TiO}_{2}$ & $500 \mathrm{ppm} \mathrm{NH}_{3}, 500 \mathrm{ppm} \mathrm{NO}, 5 \% \mathrm{O}_{2}, 5 \% \mathrm{H}_{2} \mathrm{O}, 50 \mathrm{ppm} \mathrm{SO}_{2} \mathrm{GHSV}$ at $64,000 \mathrm{~h}^{-1}$ & 200 & $\sim 95 \%$ & $\sim 90 \%$ & $\sim 93 \%$ & [46] \\
\hline $\mathrm{Ni}-\mathrm{Mn} / \mathrm{TiO}_{2}$ & $1000 \mathrm{ppm} \mathrm{NH}_{3}, 1000 \mathrm{ppm} \mathrm{NO}, 3 \% \mathrm{O}_{2}, 15 \% \mathrm{H}_{2} \mathrm{O}, 100 \mathrm{ppm} \mathrm{SO}_{2} \mathrm{GHSV}$ at $40,000 \mathrm{~h}^{-1}$ & 240 & $100 \%$ & $\sim 95 \%$ & $100 \%$ & [47] \\
\hline MnCe@CNTs & $500 \mathrm{ppm} \mathrm{NH} \mathrm{NH}_{3}, 500 \mathrm{ppm} \mathrm{NO}, 3 \% \mathrm{O}_{2}, 4 \% \mathrm{H}_{2} \mathrm{O}, 100 \mathrm{ppm} \mathrm{SO}_{2} \mathrm{GHSV}$ at $10,000 \mathrm{~h}^{-1}$ & 300 & $100 \%$ & $87 \%$ & $90 \%$ & [48] \\
\hline $\mathrm{Fe}_{2} \mathrm{O}_{3} @ \mathrm{MnO}_{\mathrm{x}} @ \mathrm{CNTs}$ & $550 \mathrm{ppm} \mathrm{NH}_{3}, 550 \mathrm{ppm} \mathrm{NO}, 5 \% \mathrm{O}_{2}, 10 \% \mathrm{H}_{2} \mathrm{O}, 100 \mathrm{ppm} \mathrm{SO}_{2} \mathrm{GHSV}$ at $20,000 \mathrm{~h}^{-1}$ & 240 & $97 \%$ & $91 \%$ & $95 \%$ & [49] \\
\hline $\mathrm{Mn}-\mathrm{Ce} / \mathrm{TiO}_{2}$-graphene & $500 \mathrm{ppm} \mathrm{NH} \mathrm{NH}_{3}, 500 \mathrm{ppm} \mathrm{NO}, 7 \% \mathrm{O}_{2}, 10 \% \mathrm{H}_{2} \mathrm{O}, 200 \mathrm{ppm} \mathrm{SO}_{2} \mathrm{GHSV}$ at $67,000 \mathrm{~h}^{-1}$ & 180 & $95 \%$ & $95 \%$ & $100 \%$ & {$[50,51]$} \\
\hline $\mathrm{MnO}_{x}(0.6) / \mathrm{Ce}_{0.5} \mathrm{Zr}_{0.5} \mathrm{O}$ & $600 \mathrm{ppm} \mathrm{NH}_{3}, 600 \mathrm{ppm} \mathrm{NO}, 3 \% \mathrm{O}_{2}, 3 \% \mathrm{H}_{2} \mathrm{O}, 200 \mathrm{ppm} \mathrm{SO}_{2} \mathrm{GHSV}$ at $30,000 \mathrm{~h}^{-1}$ & 180 & $100 \%$ & $\sim 92 \%$ & $\sim 98 \%$ & [52] \\
\hline $\mathrm{W}_{\mathrm{y}} \mathrm{SnMnCeO} \mathrm{x}_{\mathrm{x}}$ & $500 \mathrm{ppm} \mathrm{\textrm {NH } _ { 3 }}, 500 \mathrm{ppm} \mathrm{NO}, 5 \% \mathrm{O}_{2}, 5 \% \mathrm{H}_{2} \mathrm{O}, 100 \mathrm{ppm} \mathrm{SO}_{2} 60,000 \mathrm{~mL} \mathrm{~g}^{-1} \mathrm{~h}^{-1}$ & 200 & $\sim 97 \%$ & $\sim 90 \%$ & $\sim 95 \%$ & [53] \\
\hline $\mathrm{MnO}_{\mathrm{x}} / 3 \mathrm{DOMC}$ & $1000 \mathrm{ppm} \mathrm{NH}_{3}, 1000 \mathrm{ppm} \mathrm{NO}, 5 \% \mathrm{O}_{2}, 5 \% \mathrm{H}_{2} \mathrm{O}, 200 \mathrm{ppm} \mathrm{SO}_{2} \mathrm{GHSV}$ at $36,000 \mathrm{~h}^{-1}$ & 190 & $100 \%$ & $\sim 87 \%$ & $\sim 95 \%$ & [54] \\
\hline $\mathrm{W}_{0.25}-\mathrm{Mn}_{0.25}-\mathrm{Ti}_{0.5}$ & $1000 \mathrm{ppm} \mathrm{NH}_{3}, 1000 \mathrm{ppm} \mathrm{NO}, 5 \% \mathrm{O}_{2}, 10 \% \mathrm{H}_{2} \mathrm{O}, 100 \mathrm{ppm} \mathrm{SO}_{2} \mathrm{GHSV}$ at $25,000 \mathrm{~h}^{-1}$ & / & $\sim 100 \%$ & $\sim 100 \%$ & / & [55] \\
\hline
\end{tabular}

$\mathrm{X}_{\mathrm{NO}}, \mathrm{X}_{\mathrm{NO}}-\mathrm{U}$, and $\mathrm{X}_{\mathrm{NO}}-\mathrm{A}$ represent $\mathrm{NO}_{\mathrm{x}}$ conversion of regular $\mathrm{SCR}$ reaction, $\mathrm{NO}_{\mathrm{x}}$ conversion under tolerance test and after tolerance test, respectively. 


\section{The Poisoning Mechanism of Mn-Based Catalysts}

\subsection{The Poisoning Mechanism of $\mathrm{H}_{2} \mathrm{O}$}

Water vapor has a negative effect on SCR reaction mainly because of the loss of available active sites on the surface of catalysts [43,56-58]. Even under dry conditions, the catalysts can be affected by the water vapor produced in the SCR reaction [56,59]. It is believed that the poisonous effects of $\mathrm{H}_{2} \mathrm{O}$ can be generally divided into two aspects: reversible and irreversible deactivation. As shown in Figure 1, the competitive adsorption between $\mathrm{H}_{2} \mathrm{O}$ and $\mathrm{NH}_{3}$ (or $\mathrm{NO}$ ) is generally considered as the cause of reversible deactivation. Less adsorption of reacting agents on the surface leads to a decrease in $\mathrm{NO}_{x}$ conversion. Fortunately, this effect generally disappears if $\mathrm{H}_{2} \mathrm{O}$ vapors are removed [60]. The formation of additional surface hydroxyls $(-\mathrm{OH})$ caused by dissociative adsorption and decomposition of $\mathrm{H}_{2} \mathrm{O}$ on the catalyst surface is likely to be the reason of irreversible deactivation, and this effect can occur at a relatively low temperature (below $200{ }^{\circ} \mathrm{C}$ ) [61]. Because of the good thermal stability of hydroxyls (in the $250-500{ }^{\circ} \mathrm{C}$ range), the $\mathrm{NO}_{\mathrm{x}}$ conversion cannot be recovered even shutting the $\mathrm{H}_{2} \mathrm{O}$ stream down at such a low temperature, thus resulting in an irreversible deactivation [62].

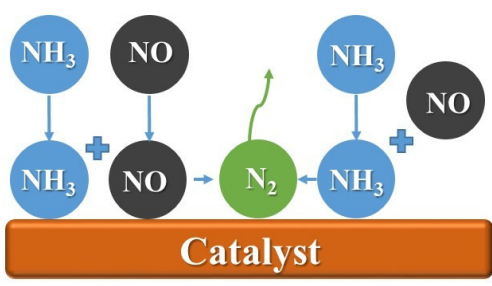

SCR Reaction

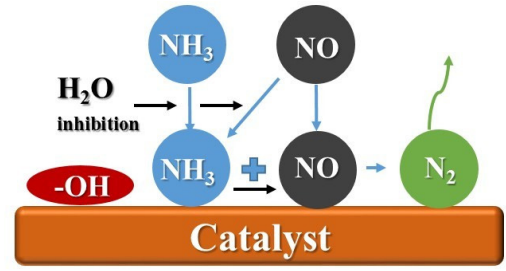

SCR Reaction with $\mathrm{H}_{2} \mathrm{O}$

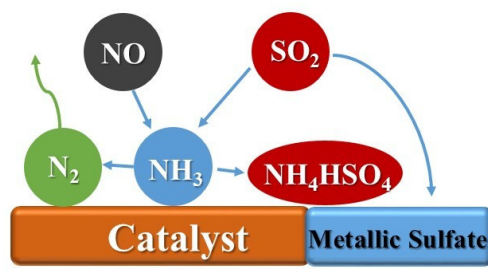

SCR Reaction with $\mathrm{SO}_{2}$

Figure 1. Scheme of the regular selective catalytic reduction (SCR) reaction, the $\mathrm{H}_{2} \mathrm{O}$ poisoning effect, and the $\mathrm{SO}_{2}$ poisoning effect.

\subsection{The Poisoning Mechanism of $\mathrm{SO}_{2}$}

The presence of a significant amount of $\mathrm{SO}_{2}$ in flue gas has a critical influence on the catalyst for SCR reaction at low temperatures. The poisonous effects of $\mathrm{SO}_{2}$ can be generally classified in two categories: reversible and irreversible deactivation. For reversible deactivation, as displayed in Figure 1, $\mathrm{SO}_{2}$ is easily oxidized to $\mathrm{SO}_{3}$, which will easily react with $\mathrm{NH}_{3}$ to generate ammonia sulfate. The ammonia sulfates $\left(\mathrm{NH}_{4} \mathrm{HSO}_{4}\right.$ and $\left.\left(\mathrm{NH}_{4}\right)_{2} \mathrm{SO}_{4}\right)$ could cover on the active sites of catalysts and lead to a decrease in $\mathrm{NO}_{\mathrm{x}}$ conversion [63-65]. In addition, the competitive adsorption between $\mathrm{SO}_{2}$ and $\mathrm{NO}$ on the active sites of the catalysts also contributes to the poisoning effect of $\mathrm{SO}_{2}$ on the SCR reaction [66]. However, the reversible effect can be eliminated by washing with water or acid solution, or high temperature treatment of catalyst. For the irreversible case, as illustrated in Figure $1, \mathrm{SO}_{2}$ (or $\mathrm{SO}_{3}$ ) can directly react with active components and form metallic sulfate, which leads to surface active site loss. Hence, the conversion decreases. Due to the high thermal stability of metallic sulfate, washing with water or high temperature treatment cannot bring much recovery of $\mathrm{NO}_{\mathrm{x}}$ conversion. When $\mathrm{H}_{2} \mathrm{O}$ and $\mathrm{SO}_{2}$ are introduced simultaneously, water will make the poisoning effect of $\mathrm{SO}_{2}$ severer, leading to a great decrease in the $\mathrm{NO}_{x}$ conversion. Mn-based catalysts can work at low temperatures, which means that the SCR unit can be installed downstream of the dust removal system and desulfurization units. According to the Chinese Standard (GB13233-2011) and the EU Standard (BREF), residual $\mathrm{SO}_{2}$ in flue gas after desulfurization (35-150 ppm depending on different fuels and desulfurization methods) is allowed. The remaining $\mathrm{SO}_{2}$ and $\mathrm{H}_{2} \mathrm{O}$ in flue gas still have inevitable effects [59,67]. Thus, developing Mn-based catalysts with good tolerance to water and sulfur is crucial for commercial applications. 


\subsection{The Effect on $\mathrm{N}_{2}$ Selectivity}

The $\mathrm{N}_{2}$ selectivity is another indicator for the evaluation of SCR catalysts, which is closely related to the yield of $\mathrm{N}_{2} \mathrm{O}$. During $\mathrm{NH}_{3}-\mathrm{SCR}$ reaction, $\mathrm{N}_{2} \mathrm{O}$ can be produced together with $\mathrm{N}_{2}$, especially at high temperatures. However, for Mn-based catalysts, some $\mathrm{N}_{2} \mathrm{O}$ can also be formed even at low temperatures due to side reactions resulting from the oxidative properties of manganese oxides, whether the $\mathrm{NH}_{3}-\mathrm{SCR}$ reaction follows the Eley-Rideal (E-R) mechanism or the Langmuir-Hinshelwood (L-H) mechanism. It has been reported that $\mathrm{H}_{2} \mathrm{O}$ presents a positive effect on $\mathrm{N}_{2}$ selectivity. Xiong et al. found that the formation of $\mathrm{N}_{2} \mathrm{O}$ over the $\mathrm{Mn}-\mathrm{Fe}$ spinel and $\mathrm{MnO}_{\mathrm{x}}-\mathrm{CeO}_{2}$ catalysts following the E- $\mathrm{R}$ mechanism was notably restrained by $\mathrm{H}_{2} \mathrm{O}$ due to the decrease in the oxidation ability of $\mathrm{MnO}_{\mathrm{x}}$, the suppression of $\mathrm{NH}_{3}$ adsorption and the inhibition of the interface reaction. Furthermore, the generation of $\mathrm{N}_{2} \mathrm{O}$ through the $\mathrm{L}-\mathrm{H}$ mechanism was completely suppressed by $\mathrm{H}_{2} \mathrm{O}$ due to the fact that the formation of $\mathrm{NH}_{4} \mathrm{NO}_{3}$ was inhibited or the decomposition of generated $\mathrm{NH}_{4} \mathrm{NO}_{3}$ was promoted [68,69]. As regards the effect of $\mathrm{SO}_{2}$ on $\mathrm{N}_{2}$ selectivity, there is a lack of research in this area at the moment.

\section{Research Progress of Mn-Based Catalysts for Water and Sulfur Resistance}

\subsection{Single $\mathrm{MnO}_{x}$ Catalysts}

It has been proven that pure $\mathrm{MnO}_{x}$ has terrific catalytic activity for the SCR of $\mathrm{NO}_{x}$ with $\mathrm{NH}_{3}$ but poor resistance to the poison of water and sulfur at low temperatures [4,70-72]. It has been reported that several factors, such as the preparation method and the specific surface area, have a great influence on the tolerance of $\mathrm{MnO}_{\mathrm{x}}$. Tang et al. prepared a series of amorphous $\mathrm{MnO}_{\mathrm{x}}$ catalysts using three methods, the solid phase reaction method (SP), the co-precipitation method (CP), and the rheological phase reaction method (RP) [13], and they found that the $\mathrm{MnO}_{x}(\mathrm{CP})$ exhibited the best sulfur and water resistance, but the $\mathrm{MnO}_{\mathrm{x}}(\mathrm{SP})$ presented a larger surface area $\left(150 \mathrm{~m}^{2} \mathrm{~g}^{-1}\right.$ for $\mathrm{MnO}_{\mathrm{x}}$ (SP) and $96 \mathrm{~m}^{2} \mathrm{~g}^{-1}$ for $\mathrm{MnO}_{\mathrm{x}}(\mathrm{CP})$ ). As shown in Figure 2, the $\mathrm{NO}_{\mathrm{x}}$ conversion at $80{ }^{\circ} \mathrm{C}$ over $\mathrm{MnO}_{\mathrm{x}}$ (CP) decreased from 98 to $73 \%$ in $3 \mathrm{~h}$. After turning off $\mathrm{SO}_{2}$ and $\mathrm{H}_{2} \mathrm{O}$, the $\mathrm{NO}_{x}$ conversion was quickly restored to $90 \%$. After the $\mathrm{MnO}_{\mathrm{x}}(\mathrm{CP})$ was heated for $1-2 \mathrm{~h}$ in $\mathrm{N}_{2}$ at $280^{\circ} \mathrm{C}$, its activity was restored to the initial level. Kang et al. prepared two $\mathrm{MnO}_{\mathrm{x}}$ catalysts using sodium carbonate (SC) and ammonia (AH) as precipitants [23]. They found that an $\mathrm{MnO}_{\mathbf{x}}$-SC catalyst showed better SCR activity and great sulfur and water tolerance, and they ascribed this to the larger surface area $\left(173.3 \mathrm{~m}^{2} / \mathrm{g}\right.$ for $\mathrm{MnO}_{\mathrm{x}}-\mathrm{SC}$ and $18.7 \mathrm{~m}^{2} / \mathrm{g}$ for $\left.\mathrm{MnO}_{\mathrm{x}}-\mathrm{AH}\right)$. As displayed in Figure 3, the $\mathrm{NO}_{\mathrm{x}}$ conversion over the $\mathrm{MnO}_{\mathrm{x}}-\mathrm{SC}$ catalyst was decreased from 100 to $94 \%$ after both $\mathrm{SO}_{2}(100 \mathrm{ppm})$ and $\mathrm{H}_{2} \mathrm{O}(11 \mathrm{vol} \%)$ were fed into the reaction system with aspace velocity of $50,000 \mathrm{~h}^{-1}$, which is still very high de- $\mathrm{NO}_{\mathrm{x}}$ activity at $120^{\circ} \mathrm{C}$. Moreover, its activity was rapidly recovered to $100 \%$ after the supply of $\mathrm{SO}_{2}$ and $\mathrm{H}_{2} \mathrm{O}$ was cut off.

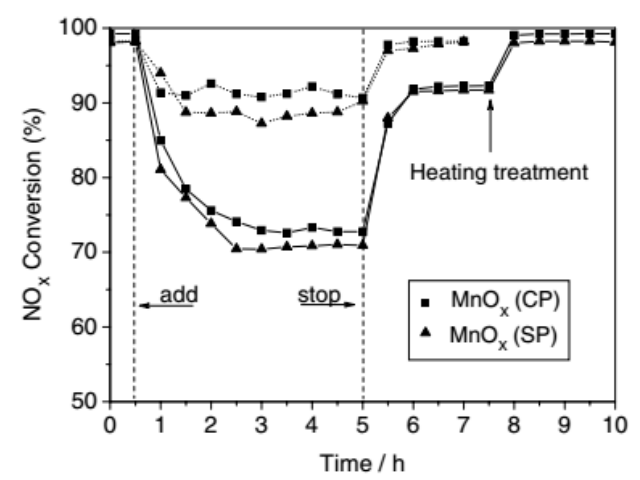

Figure 2. The effect of $\mathrm{SO}_{2}$ and $\mathrm{H}_{2} \mathrm{O}$ on $\mathrm{NO}_{\mathrm{x}}$ conversion over $\mathrm{MnO}_{\mathrm{x}}(\mathrm{CP})$ and $\mathrm{MnO}_{\mathrm{x}}(\mathrm{SP}$ ) (dotted line:

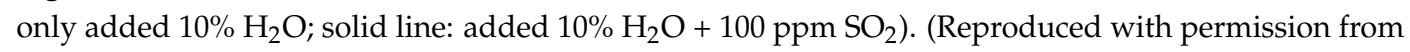
Reference [13], Copyright 2007, Elsevier). 


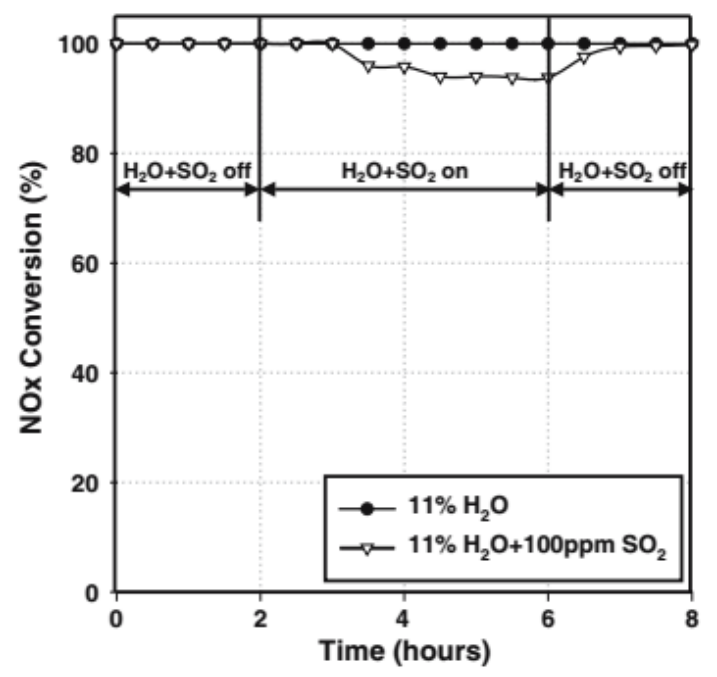

Figure 3. The effects of $\mathrm{H}_{2} \mathrm{O}$ and $\mathrm{SO}_{2}$ on $\mathrm{NO}_{x}$ conversions over $\mathrm{MnO}_{\mathrm{x}}-\mathrm{SC}$ catalyst at $120{ }^{\circ} \mathrm{C}$. Reactants: 500 ppm NO, $500 \mathrm{ppm} \mathrm{NH}_{3}, 5 \mathrm{vol} \% \mathrm{O}_{2}$ in $\mathrm{N}_{2}$. The gas hourly space velocity (GHSV) was $50,000 \mathrm{~h}^{-1}$. (Reproduced with permission from Reference [23], Copyright 2006, Springer).

\subsection{Mn-Based Multi-Metal Oxide Catalysts}

It has been widely demonstrated that mixing or doping $\mathrm{MnO}_{\mathrm{x}}$ with other metal oxides can greatly improve the water and sulfur resistance of single $\mathrm{MnO}_{\mathrm{x}}$ catalysts because of the synergistic effect between them [73]. For Mn-based binary metal oxide catalysts, it has been reported that different dopants have different effects on the improvement of the tolerance to water and sulfur [74,75]. For Mn-based ternary metal oxide catalysts, the modification of a small amount of a third element can enhance the synergistic effect resulted from the changes in both electronic and structural properties.

\subsubsection{Mn-Based Binary Metal Oxide Catalysts}

Among the metal elements, cerium [24,25], chromium [10], iron [27,28,76], cobalt [29,30], copper [52], nickel [77], and several other elements have drawn the most attention as the mixture or dopant to construct binary metal oxide catalysts with $\mathrm{MnO}_{\mathrm{x}} \cdot \mathrm{CeO}_{2}$ has been studied extensively due to its good characteristics, such as increasing surface acidity after $\mathrm{SO}_{2}$ poisoning [78,79], high surface area [80,81], good dispersion of $\mathrm{MnO}_{\mathrm{x}}$ on the surface [45], and the redox shift between $\mathrm{Ce}^{4+}$ and $\mathrm{Ce}^{3+}$. It should be noted that the shift between $\mathrm{Ce}^{4+}$ and $\mathrm{Ce}^{3+}$ can result in the formation of oxygen vacancies and anincrease in the chemisorbed oxygen on the surface of Mn-Ce binary metal oxide catalysts, which are helpful for the enhancement of water and sulfur resistance [25,82]. Qi and Yang [24] reported that the $\mathrm{Mn}-\mathrm{Ce}$ catalyst with a proper mole ratio $(\mathrm{Mn} /(\mathrm{Mn}+\mathrm{Ce})=0.3)$ showed great tolerance to water and sulfur. As illustrated in Figure 4, the NO conversion over an Mn-Ce catalyst gradually decreased from 100 to $95 \%$ within $4 \mathrm{~h}$ after $100 \mathrm{ppm} \mathrm{SO}_{2}$ and $2.5 \% \mathrm{H}_{2} \mathrm{O}$ were added to the reaction gas at $120{ }^{\circ} \mathrm{C}$. Moreover, the $\mathrm{NO}$ conversion was restored after $\mathrm{SO}_{2}+\mathrm{H}_{2} \mathrm{O}$ was stopped. Liu et al. prepared an $\mathrm{Mn}-\mathrm{Ce}$ catalyst by the surfactant-template method using hexadecyltrimethyl ammonium bromide (CTAB) as the template. The obtained $\mathrm{Mn}_{5} \mathrm{Ce}_{5}(\mathrm{ST})$ catalyst presented a noticeable decrease in the catalytic activity for the $\mathrm{NO}_{\mathrm{x}}$ conversion at $100{ }^{\circ} \mathrm{C}$ in the presence of $\mathrm{H}_{2} \mathrm{O}$ and $\mathrm{SO}_{2}$ (Figure 5), a slight inhibiting effect was observed from 150 to $200{ }^{\circ} \mathrm{C}$, and the promoting effect was exhibited above $200{ }^{\circ} \mathrm{C}$ [25]. Yao et al. successfully prepared a series of $\mathrm{Mn} / \mathrm{CeO}_{2}$ catalysts via impregnation using deionized water, anhydrous ethanol, acetic acid, and oxalic acid as a solvent and found that $\mathrm{Mn} / \mathrm{Ce}-\mathrm{OA}$ (oxalic acid) exhibited the best water and sulfur tolerance among all catalysts (Figure 6) [26]. Chen et al. [10] found that the $\mathrm{SO}_{2}$ tolerance of $\mathrm{MnO}_{\mathrm{x}}$ was dramatically enhanced by the introduction of $\mathrm{Cr}$ due to the formation of $\mathrm{CrMn}_{1.5} \mathrm{O}_{4}$. 


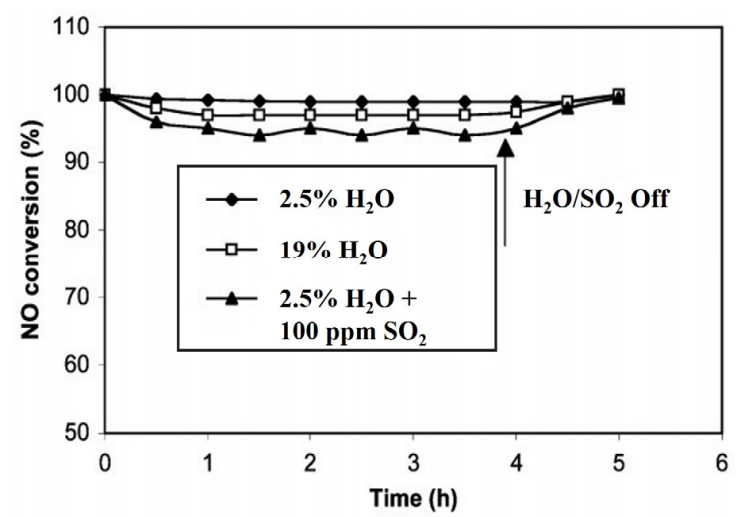

Figure 4. The effect of on-stream time on SCR activity with $\mathrm{H}_{2} \mathrm{O}+\mathrm{SO}_{2}$ and without $\mathrm{H}_{2} \mathrm{O}+\mathrm{SO}_{2}$ (Reaction conditions: $120^{\circ} \mathrm{C},\left[\mathrm{NH}_{3}\right]=[\mathrm{NO}]=1000 \mathrm{ppm},\left[\mathrm{O}_{2}\right]=2 \%, \mathrm{GHSV}=42,000 \mathrm{~h}^{-1}$. Catalyst: $\mathrm{MnO}_{\mathrm{x}}(0.3)-\mathrm{CeO}_{2}$ ). (Reproduced with permission from Reference [24], Copyright 2003, The Royal Society of Chemistry).

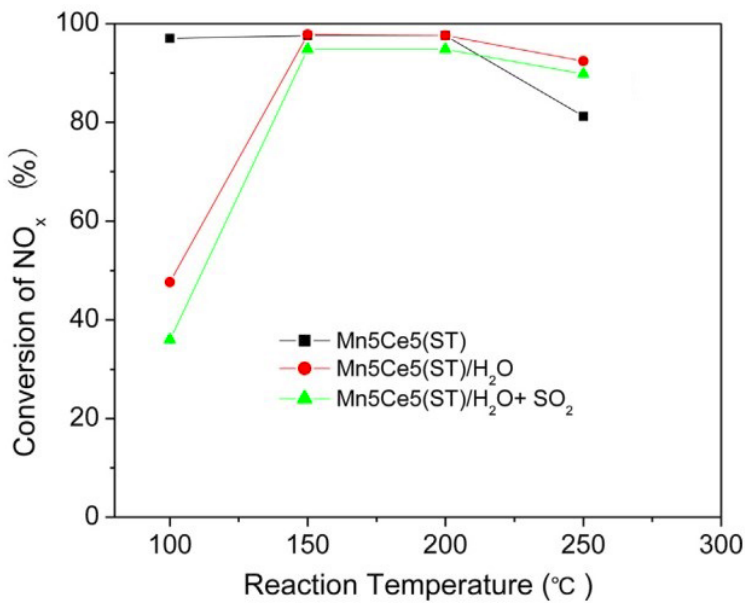

Figure 5. Catalytic performance of $\mathrm{Mn}_{5} \mathrm{Ce}_{5}(\mathrm{ST})$ catalysts in the presence of $\mathrm{H}_{2} \mathrm{O}$ and $\mathrm{SO}_{2}$ (Reaction conditions: $\mathrm{NO}=500 \mathrm{ppm}, \mathrm{NH}_{3}=500 \mathrm{ppm}, \mathrm{O}_{2}=5 \%, \mathrm{H}_{2} \mathrm{O}=5 \%, \mathrm{SO}_{2}=50 \mathrm{ppm}, \mathrm{GHSV}=64,000 \mathrm{~h}^{-1}$ ). (Reproduced with permission from Reference [25], Copyright 2013, Elsevier).

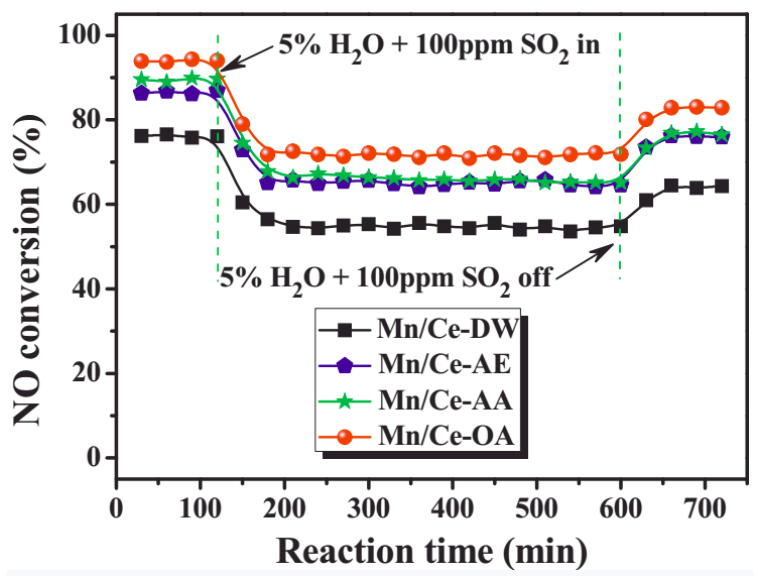

Figure 6. The effect of $\mathrm{H}_{2} \mathrm{O}$ and $\mathrm{SO}_{2}$ on $\mathrm{NO}$ conversion for $\mathrm{Mn} / \mathrm{CeO}_{2}$ catalysts (Reaction conditions: $[\mathrm{NO}]=\left[\mathrm{NH}_{3}\right]=500 \mathrm{ppm},\left[\mathrm{O}_{2}\right]=5 \mathrm{vol} \%,\left[\mathrm{SO}_{2}\right]=100 \mathrm{ppm},\left[\mathrm{H}_{2} \mathrm{O}\right]=5 \mathrm{vol} \%, \mathrm{~N}_{2}$ balance, $\mathrm{T}=200{ }^{\circ} \mathrm{C}$, $60,000 \mathrm{~mL} \mathrm{~g}^{-1} \mathrm{~h}^{-1}$ ). (Reproduced with permission from Reference [26], Copyright 2017, Elsevier). 
Iron is another potential element that has been demonstrated to play a positive role in the sulfur and water tolerance of Mn-based catalysts. Long et al. [27] observed that Fe-Mn-based transition metal oxides were resistant to $\mathrm{H}_{2} \mathrm{O}$ and $\mathrm{SO}_{2}$ at $140-180{ }^{\circ} \mathrm{C}$ (Figure 7). Chen et al. [28] found that the $\mathrm{NO}$ conversion over an Fe-Mn mixed oxide catalyst decreased slightly from 100 to $87 \%$ in $4 \mathrm{~h}$ at $120^{\circ} \mathrm{C}$ in the presence of $5 \% \mathrm{H}_{2} \mathrm{O}$ and $100 \mathrm{ppm} \mathrm{SO}_{2}$, which could be restored to $93 \%$ after the stopping of both $\mathrm{SO}_{2}$ and $\mathrm{H}_{2} \mathrm{O}$ (Figure 8). They attributed the enhanced resistance to the formed $\mathrm{Fe}_{3} \mathrm{Mn}_{3} \mathrm{O}_{8}$ phase in Fe-Mn mixed oxides. Yang et al. [76] prepared an Mn-Fe spinel catalyst and found that the NO conversion over $\mathrm{Mn}-\mathrm{Fe}$ spinel catalyst decreased from 100 to about $60 \%$ after the addition of $\mathrm{H}_{2} \mathrm{O}$ and $\mathrm{SO}_{2}$ for $100 \mathrm{~min}$, and the $\mathrm{NO}$ conversion could be recovered to the original level after washing catalyst with water.

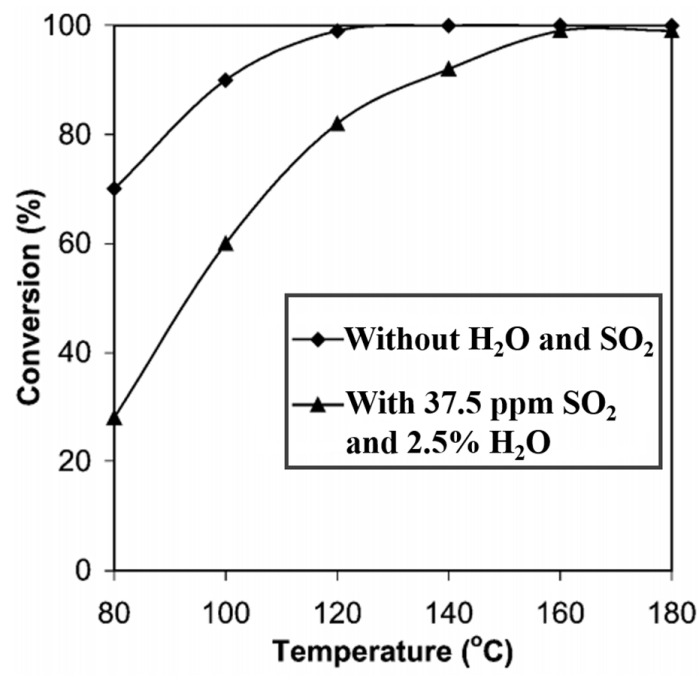

Figure 7. SCR activities on the Fe-Mn-based transition metal oxides in the presence of $\mathrm{SO}_{2}+\mathrm{H}_{2} \mathrm{O}$ (Reaction conditions: $0.5 \mathrm{~g}$ catalyst, $[\mathrm{NO}]=\left[\mathrm{NH}_{3}\right]=1000 \mathrm{ppm},\left[\mathrm{O}_{2}\right]=2 \%,\left[\mathrm{SO}_{2}\right]=37.5 \mathrm{ppm}$ and $\left[\mathrm{H}_{2} \mathrm{O}\right]=2.5 \%$ (when used), $\mathrm{He}=$ balance, total flow rate $=100 \mathrm{~mL} / \mathrm{min}$, and GHSV $=15,000 \mathrm{~h}^{-1}$ ). (Reproduced with permission from Reference [27], Copyright 2002, The Royal Society of Chemistry.).

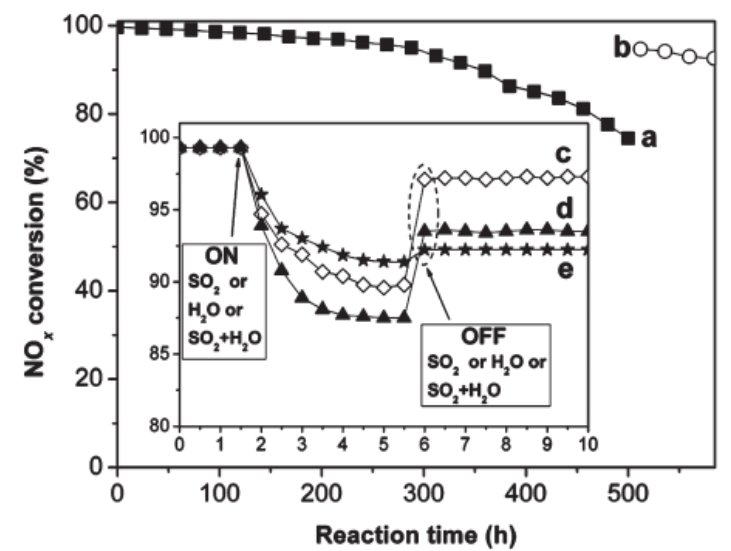

Figure 8. Lifetime, $\mathrm{SO}_{2}$ tolerance, and water resistance of $\mathrm{Fe}-(0.4) \mathrm{MnO}_{\mathrm{x}}(\mathrm{CA}-500)$ catalyst (Reaction conditions: $120{ }^{\circ} \mathrm{C},[\mathrm{NO}]=\left[\mathrm{NH}_{3}\right]=1000 \mathrm{ppm},\left[\mathrm{O}_{2}\right]=3 \%,\left[\mathrm{SO}_{2}\right]=100 \mathrm{ppm},\left[\mathrm{H}_{2} \mathrm{O}\right]=5 \%, \mathrm{~N}_{2}$ as balance, and GHSV $=30,000 \mathrm{~h}^{-1}$; Plasma treatment conditions: $10 \mathrm{MHz}, 25^{\circ} \mathrm{C}$, pure oxygen with $50 \mathrm{~mL} / \mathrm{min}$ under $2.4 \mathrm{~s}$ of residence time, and duration of $6 \mathrm{~h}$ ): (a) Lifetime testing; (b) regeneration property; (c) $\mathrm{SO}_{2}$ tolerance; (d) water resistance; (e) the combined effect of $\mathrm{SO}_{2}$ and $\mathrm{H}_{2} \mathrm{O}$. (Reproduced with permission from Reference [28], Copyright 2012, American Chemical Society.). 
It has been reported that cobalt also presents a positive role on the tolerance of Mn-based catalysts to sulfur and water. Zhang et al. [29] found that the $\mathrm{Mn}_{\mathrm{x}} \mathrm{Co}_{3-\mathrm{x}} \mathrm{O}_{4}$ nanocage catalyst exhibited decent $\mathrm{SO}_{2}$ tolerance due to its hierarchically porous structure, abundant active sites, and strong interaction between $\mathrm{Mn}$ and $\mathrm{Co}$ oxides (Figure 9). Qiu et al. prepared a mesoporous 3D- $\mathrm{MnCo}_{2} \mathrm{O}_{4}$ catalyst, which exhibited great SCR activity and good tolerance to sulfur and water [30,31]. As illustrated in Figure 10, the $\mathrm{NO}$ conversion over $\mathrm{MnCo}_{2} \mathrm{O}_{4}$ was maintained at $86 \%$ in the presence of $5 \mathrm{vol} \% \mathrm{H}_{2} \mathrm{O}$ and $100 \mathrm{ppm} \mathrm{SO}_{2}$. Futhermore, the $\mathrm{NO}$ conversion could be recovered to $93 \%$ after the supply of $\mathrm{H}_{2} \mathrm{O}$ and $\mathrm{SO}_{2}$ was cut off.

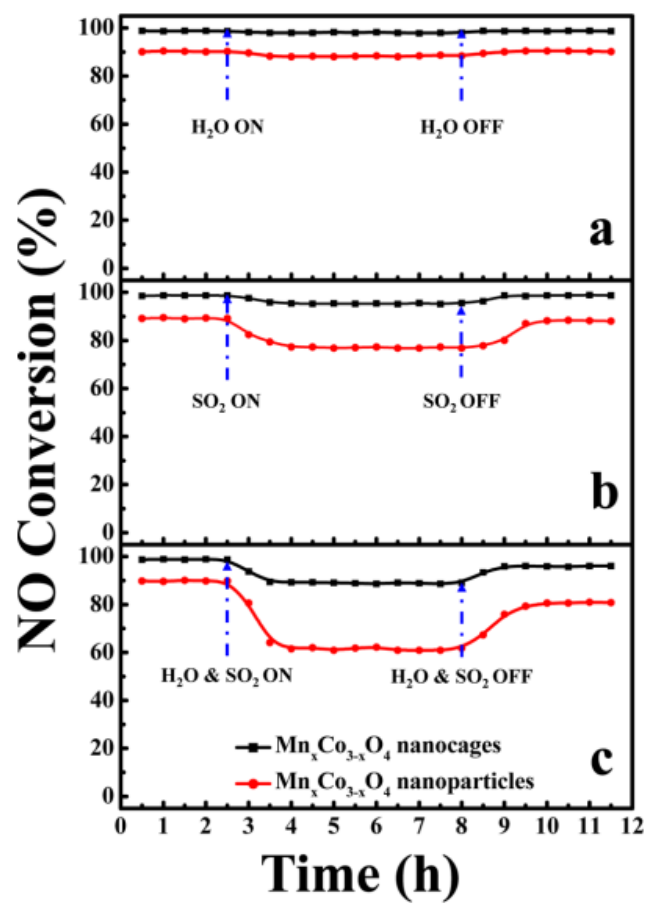

Figure 9. (a) $\mathrm{H}_{2} \mathrm{O}$ resistance, (b) $\mathrm{SO}_{2}$ tolerance, and (c) $\mathrm{H}_{2} \mathrm{O}$ and $\mathrm{SO}_{2}$ synergetic effect study of the catalysts at $175{ }^{\circ} \mathrm{C}$ (Reaction conditions: $[\mathrm{NO}]=\left[\mathrm{NH}_{3}\right]=500 \mathrm{ppm},\left[\mathrm{O}_{2}\right]=3 \mathrm{vol} \%,\left[\mathrm{H}_{2} \mathrm{O}\right]=8 \mathrm{vol} \%$ (when used), $\left[\mathrm{SO}_{2}\right]=200 \mathrm{ppm}$ (when used), $\mathrm{N}_{2}$ balance, and GHSV $=38,000 \mathrm{~h}^{-1}$ ). (Reproduced with permission from Reference [29], Copyright 2014, American Chemical Society.).

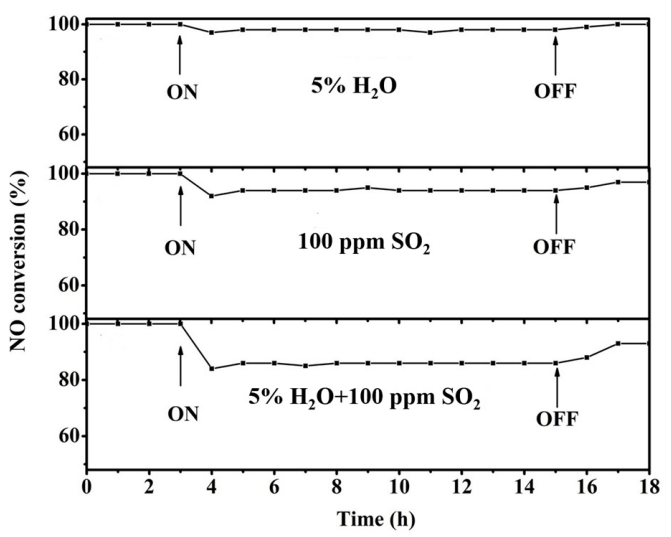

Figure 10. $\mathrm{H}_{2} \mathrm{O}$ resistance, $\mathrm{SO}_{2}$ tolerance, and $\mathrm{H}_{2} \mathrm{O}$ and $\mathrm{SO}_{2}$ synergetic effect study of the $\mathrm{MnCo}_{2} \mathrm{O}_{4}$ catalyst at $200{ }^{\circ} \mathrm{C}$ (Reaction conditions: $[\mathrm{NO}]=\left[\mathrm{NH}_{3}\right]=500 \mathrm{ppm},\left[\mathrm{O}_{2}\right]=\left[\mathrm{H}_{2} \mathrm{O}\right]=5 \mathrm{vol} \%$, $\left[\mathrm{SO}_{2}\right]=100 \mathrm{ppm}, \mathrm{N}_{2}$ balance, and $\mathrm{GHSV}=50,000 \mathrm{~h}^{-1}$ ). (Reproduced with permission from Reference [30], Copyright 2015, Elsevier). 
Copper also presents a positive effect on the tolerance of $\mathrm{MnO}_{\mathrm{x}}$-based catalysts to water and sulfur. Kang et al. reported a $\mathrm{Cu}-\mathrm{Mn}$ mixed oxide catalyst, which exhibited good tolerance to water and sulfur [32]. When $100 \mathrm{ppm} \mathrm{SO} \mathrm{S}_{2}$ and $11 \mathrm{vol} \% \mathrm{H}_{2} \mathrm{O}$ were added to the reaction gas, the $\mathrm{NO}_{\mathrm{x}}$ conversion over $\mathrm{Cu}-\mathrm{Mn}$ oxides decreased from 95 to $64 \%$ at $125^{\circ} \mathrm{C}$ after $4 \mathrm{~h}$, and the $\mathrm{NO}_{\mathrm{x}}$ conversion was gradually recovered after stopping the supply of $\mathrm{SO}_{2}$ and $\mathrm{H}_{2} \mathrm{O}$.

Recently, several rare earth elements have been demonstrated to promote the enhanced tolerance to sulfur and water. For instance, Meng et al. developed a Sm-modified $\mathrm{MnO}_{\mathrm{x}}$ catalyst [33], and found that a proper $\mathrm{Sm}$ modification $(\mathrm{Sm} / \mathrm{Mn}=1: 10)$ enhanced the sulfur and water tolerance of $\mathrm{MnO}_{\mathrm{x}}$. As shown in Figure 11, the $\mathrm{NO}_{\mathrm{x}}$ conversion over the $\mathrm{Sm}-\mathrm{Mn}-0.1$ catalyst could be maintained at about $91 \%$ at $100{ }^{\circ} \mathrm{C}$ when $2 \% \mathrm{H}_{2} \mathrm{O}$ and $100 \mathrm{ppm} \mathrm{SO}_{2}$ were added into the feed gas, and the $\mathrm{NO}_{\mathrm{x}}$ conversion was recovered to $97 \%$ after both $\mathrm{H}_{2} \mathrm{O}$ and $\mathrm{SO}_{2}$ were removed from the feed gas. Sun et al. prepared a Eu-modified $\mathrm{MnO}_{\mathrm{x}}$ catalyst [34]. They tested the sulfur and water resistance of this catalyst at a higher temperature $\left(350^{\circ} \mathrm{C}\right)$, instead of a low temperature, such as $100^{\circ} \mathrm{C}$. The deactivation effect of $\mathrm{SO}_{2}$ and $\mathrm{H}_{2} \mathrm{O}$ on $\mathrm{MnEuO}_{\mathrm{x}}-0.1$ was weak, and the $\mathrm{NO}_{\mathrm{x}}$ conversion over $\mathrm{MnEuO}_{\mathrm{x}}-0.1$ kept over $90 \%$ in the presence of $100 \mathrm{ppm} \mathrm{SO} \mathrm{S}_{2}$ and $5 \% \mathrm{H}_{2} \mathrm{O}$. Furthermore, the $\mathrm{NO}_{\mathrm{x}}$ conversion nearly recovered its original level after the supply of $\mathrm{SO}_{2}$ and $\mathrm{H}_{2} \mathrm{O}$ was cut off (Figure 12).

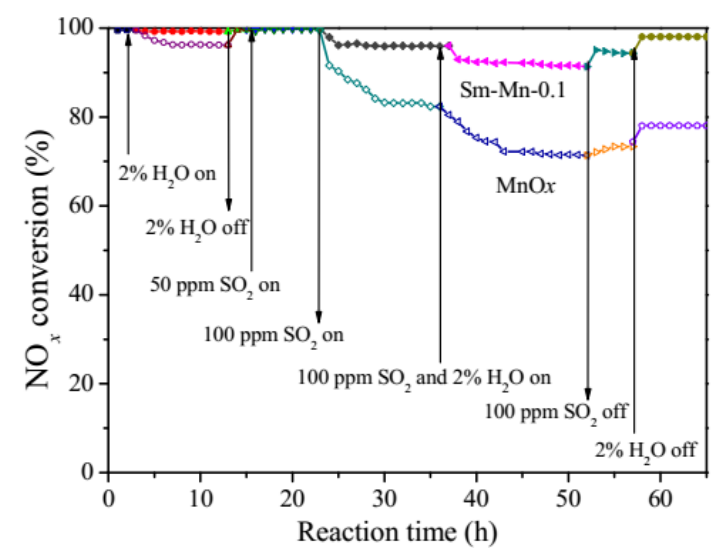

Figure 11. The effect of $\mathrm{H}_{2} \mathrm{O}$ and $\mathrm{SO}_{2}$ on the catalytic activities of the $\mathrm{MnO}_{\mathrm{x}}$ and $\mathrm{Sm}-\mathrm{Mn}-0.1$ catalysts for the SCR reaction at $100{ }^{\circ} \mathrm{C}$ (Reaction conditions: $0.3 \mathrm{~g}$ catalyst, $500 \mathrm{ppm} \mathrm{NO}, 500 \mathrm{ppm} \mathrm{NH}, 5 \% \mathrm{O}_{2}$, Ar to balance, GHSV $=49,000 \mathrm{~h}^{-1}$ ). (Reproduced with permission from Reference [33], Copyright 2016, American Chemical Society).

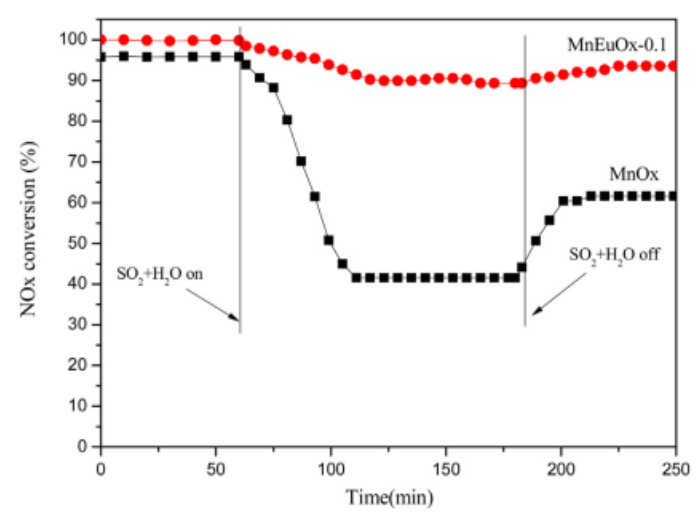

Figure 12. Effect of $\mathrm{SO}_{2}$ and $\mathrm{H}_{2} \mathrm{O}$ on the SCR activities of $\mathrm{MnO}_{\mathrm{x}}$ and $\mathrm{MnEuO}_{\mathrm{x}}-0.1$ catalysts (Reaction conditions: $[\mathrm{NO}]=\left[\mathrm{NH}_{3}\right]=600 \mathrm{ppm},\left[\mathrm{SO}_{2}\right]=100 \mathrm{ppm},\left[\mathrm{H}_{2} \mathrm{O}\right]=\left[\mathrm{O}_{2}\right]=5 \%$, balance Ar, $\mathrm{GHSV}=108,000 \mathrm{~h}^{-1}$, reaction temperature $=350^{\circ} \mathrm{C}$ ). (Reproduced with permission from Reference [34], Copyright 2017, Elsevier). 


\subsubsection{Mn-Based Ternary Metal Oxide Catalysts}

It has been reported that the introduction of a small amount of a third element can enhance the tolerance of Mn-based binary metal oxide catalysts to $\mathrm{H}_{2} \mathrm{O}$ and $\mathrm{SO}_{2}$. Qi et al. successfully prepared $\mathrm{Mn}-\mathrm{Fe}-\mathrm{Ce}$ mixed oxides that performed well under $100 \mathrm{ppm} \mathrm{SO}_{2}$ and $2.5 \% \mathrm{H}_{2} \mathrm{O}$ condition (Figure 13) [35]. The NO conversion over Mn-Fe-Ce decreased from 98 to $95 \%$ in $3 \mathrm{~h}$ in the presence of $\mathrm{SO}_{2}$ and $\mathrm{H}_{2} \mathrm{O}$ and then restored quickly to its original level after the supply of $\mathrm{SO}_{2}$ and $\mathrm{H}_{2} \mathrm{O}$ was cut off. France et al. developed a $\mathrm{CeFeMnO}_{x}$ catalyst that exhibited excellent sulfur and water resistance at a low temperature [36]. As presented in Figure 14, the NO conversion over this catalyst only decreased from 100 to $75 \%$ when water and sulfur were introduced, and then recovered to $95 \%$ after the supply of $\mathrm{H}_{2} \mathrm{O}$ and $\mathrm{SO}_{2}$ was cut off. Chang et al. found that $\mathrm{Sn}$ doping could enhance the sulfur resistance of $\mathrm{Mn}-\mathrm{Ce}$ catalysts because $\mathrm{SO}_{2}$ was easier to react with $\mathrm{Ce}$ on the surface instead of forming ammonia sulfate; meanwhile, more surface acid sites were introduced due to Sn doping [37,38]. As shown in Figure 15, the $\mathrm{NO}$ conversion was kept at around $70 \%$ in the presence of $\mathrm{SO}_{2}$ and $\mathrm{H}_{2} \mathrm{O}$ and recovered to almost the original level within less than 3 hafter $\mathrm{SO}_{2}$ and $\mathrm{H}_{2} \mathrm{O}$ were removed. Gao et al. [39] found that the SCR pathways over $\mathrm{MnO}_{\mathrm{x}}-\mathrm{CeO}_{2}$ catalyst are based on the adsorption, activation, and reaction of monodentate nitrite species and coordinated $\mathrm{NH}_{3}$ species, and these species are significantly inhibited by $\mathrm{SO}_{2}$ through competitive adsorption. In contrast, over $\mathrm{Co}$ - and $\mathrm{Ni}$-doped $\mathrm{MnO}_{\mathrm{x}}-\mathrm{CeO}_{2}$ catalysts, the primary $\mathrm{NO}_{\mathrm{x}}$ adsorbed species are in the form of bidentate nitrate without the influence by $\mathrm{SO}_{2}$. The $\mathrm{NO}$ conversion over $\mathrm{Co}-$ and $\mathrm{Ni}$-doped $\mathrm{MnO}_{\mathrm{x}}-\mathrm{CeO}_{2}$ catalysts decreased $20 \%$ after $150 \mathrm{ppm} \mathrm{SO}_{2}$ and $10 \% \mathrm{H}_{2} \mathrm{O}$ were introduced, and recovered after the supply of $\mathrm{SO}_{2}$ and $\mathrm{H}_{2} \mathrm{O}$ was cut off (Figure 16). $\mathrm{Liu}$ et al. successfully prepared $\mathrm{WO}_{3}$ promoted $\mathrm{Mn}-\mathrm{Zr}$ mixed oxide catalyst [40]. As shown in Figure 17, the $\mathrm{NO}_{x}$ conversion over MnWZr catalyst was maintained above $90 \%$ in the presence of 50 ppm $\mathrm{SO}_{2}$ and $5 \% \mathrm{H}_{2} \mathrm{O}$, and the conversion quickly recovered after the supply of $\mathrm{SO}_{2}$ and $\mathrm{H}_{2} \mathrm{O}$ was cut off.

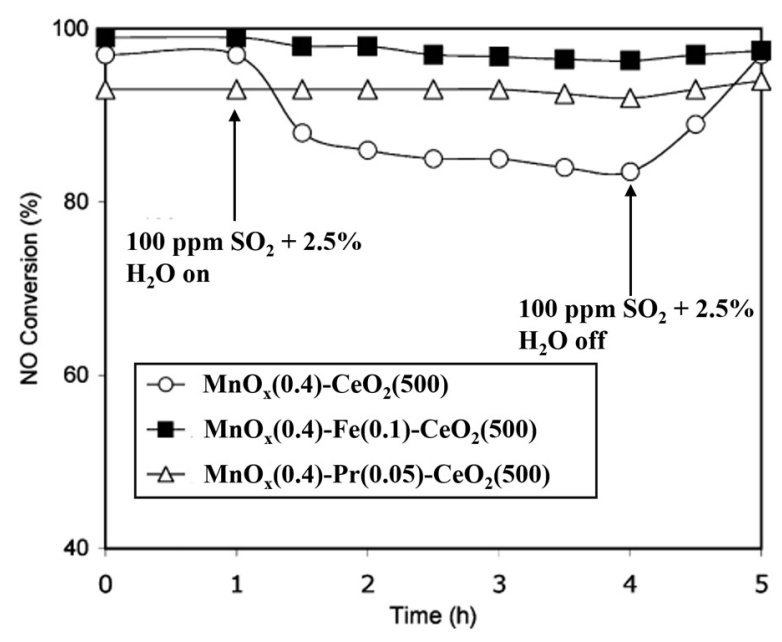

Figure 13. The effects of $\mathrm{SO}_{2}$ and $\mathrm{H}_{2} \mathrm{O}$ on the SCR activities of $\mathrm{MnO}_{x}(0.4)-\mathrm{CeO}_{2}(500)$-based catalysts (Reaction conditions: $0.2 \mathrm{~g}$ catalyst, $\left[\mathrm{NH}_{3}\right]=[\mathrm{NO}]=1000 \mathrm{ppm},\left[\mathrm{O}_{2}\right]=2 \%, \mathrm{He}=$ balance and total flow rate $=100 \mathrm{~mL} / \mathrm{min}, T=150{ }^{\circ} \mathrm{C}$ ). (Reproduced with permission from Reference [35], Copyright 2004, Elsevier). 


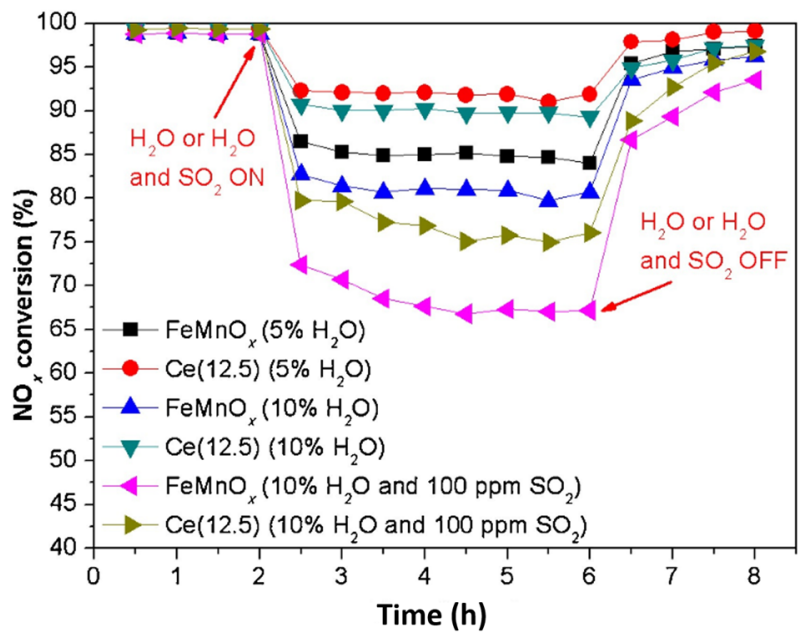

Figure 14. Influence of $\mathrm{H}_{2} \mathrm{O}$ and combined $\mathrm{H}_{2} \mathrm{O}$ and $\mathrm{SO}_{2}$ on $\mathrm{NO}_{\mathrm{x}}$ conversion of $\mathrm{FeMnO}_{\mathrm{x}}$ and $\mathrm{Ce}(12.5)$ (Reaction conditions: $[\mathrm{NO}]=\left[\mathrm{NH}_{3}\right]=0.1 \%,\left[\mathrm{H}_{2} \mathrm{O}\right]=5 \%$ or $10 \%,\left[\mathrm{SO}_{2}\right]=100 \mathrm{ppm},\left[\mathrm{O}_{2}\right]=3 \%, \mathrm{~N}_{2}$ balance, $\mathrm{GHSV}=30,000 \mathrm{~h}^{-1}$; reaction temperature $=120^{\circ} \mathrm{C}$ ). (Reproduced with permission from Reference [36], Copyright 2017, Elsevier).
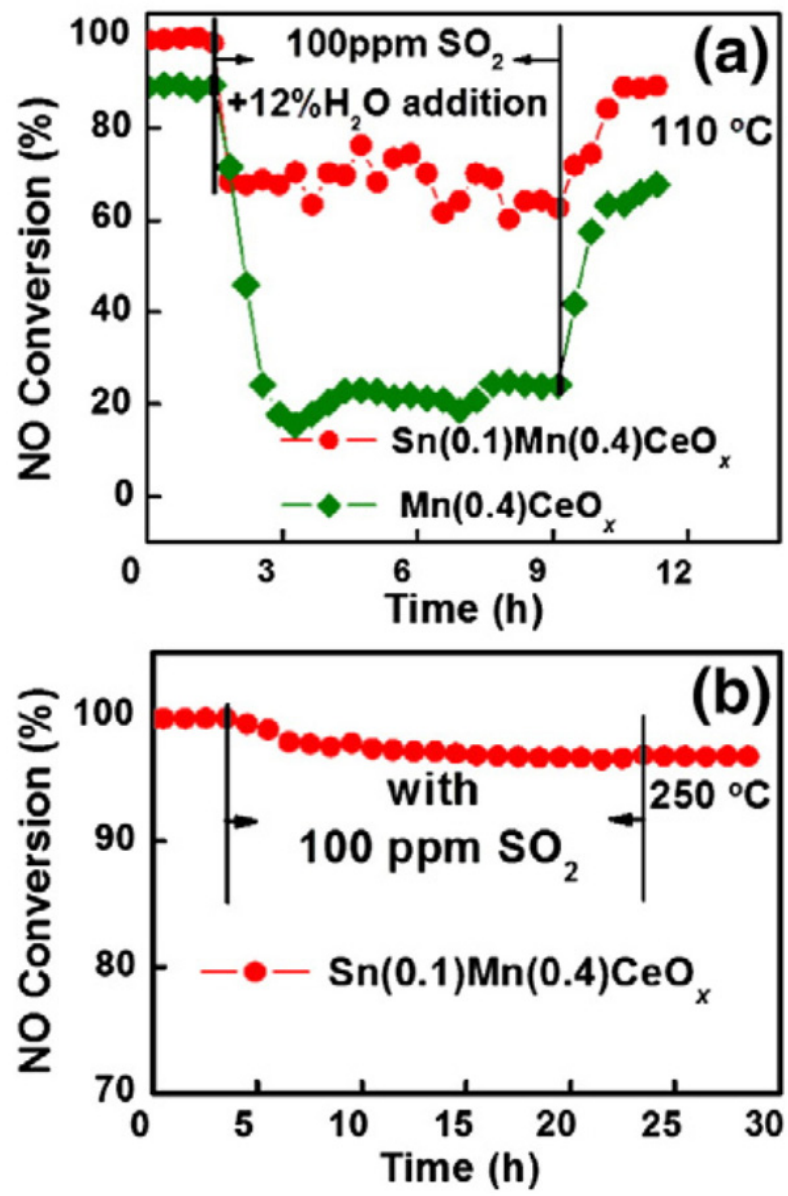

Figure 15. (a) $\mathrm{NO}$ conversion in the presence of $100 \mathrm{ppm} \mathrm{SO}_{2}$ and $12 \% \mathrm{H}_{2} \mathrm{O}$ at $110{ }^{\circ} \mathrm{C}$; (b) $\mathrm{NO}$ conversion in the presence of $100 \mathrm{ppm} \mathrm{SO}_{2}$ at $250{ }^{\circ} \mathrm{C}$ (Reaction conditions: $0.2 \mathrm{~g}$ samples, $1000 \mathrm{ppm} \mathrm{NO}, 1000 \mathrm{ppm}$ $\mathrm{NH}_{3}, 2 \% \mathrm{O}_{2}, \mathrm{~N}_{2}$ balance, GHSV $=35,000 \mathrm{~h}^{-1}$ ). (Reproduced with permission from Reference [37], Copyright 2012, Elsevier). 


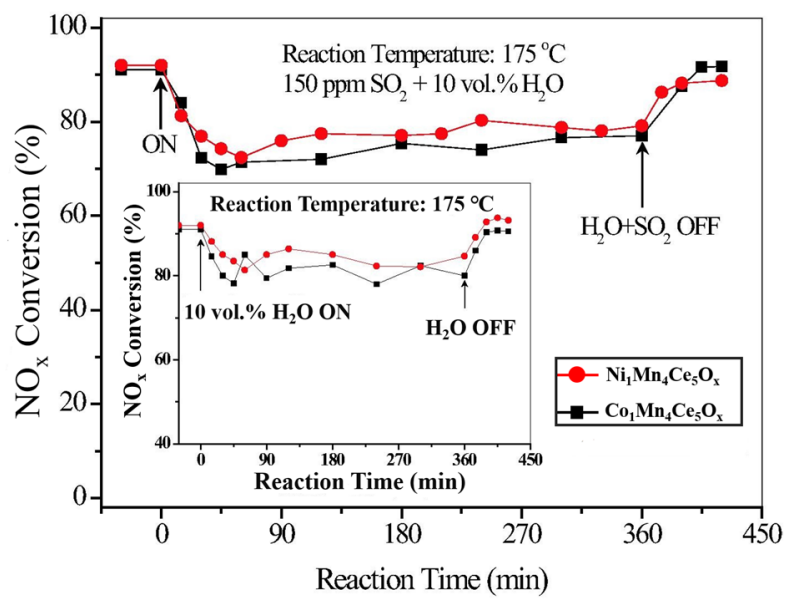

Figure 16. The resistance to $\mathrm{H}_{2} \mathrm{O}$ and/or $\mathrm{SO}_{2}$ over $\mathrm{Co}_{1} \mathrm{Mn}_{4} \mathrm{Ce}_{5} \mathrm{O}_{\mathrm{x}}$ and $\mathrm{Ni}_{1} \mathrm{Mn}_{4} \mathrm{Ce}_{5} \mathrm{O}_{\mathrm{x}}$ (Reaction conditions: $[\mathrm{NO}]=\left[\mathrm{NH}_{3}\right]=500 \mathrm{ppm},\left[\mathrm{O}_{2}\right]=5 \mathrm{vol} \%,\left[\mathrm{SO}_{2}\right]=150 \mathrm{ppm},\left[\mathrm{H}_{2} \mathrm{O}\right]=10 \mathrm{vol} \%, \mathrm{~N}_{2}$ to balance, total flow rate $=200 \mathrm{~mL} / \mathrm{min}, \mathrm{GHSV}=48,000 \mathrm{~h}^{-1}$ ). (Reproduced with permission from Reference [39], Copyright 2017, Elsevier).

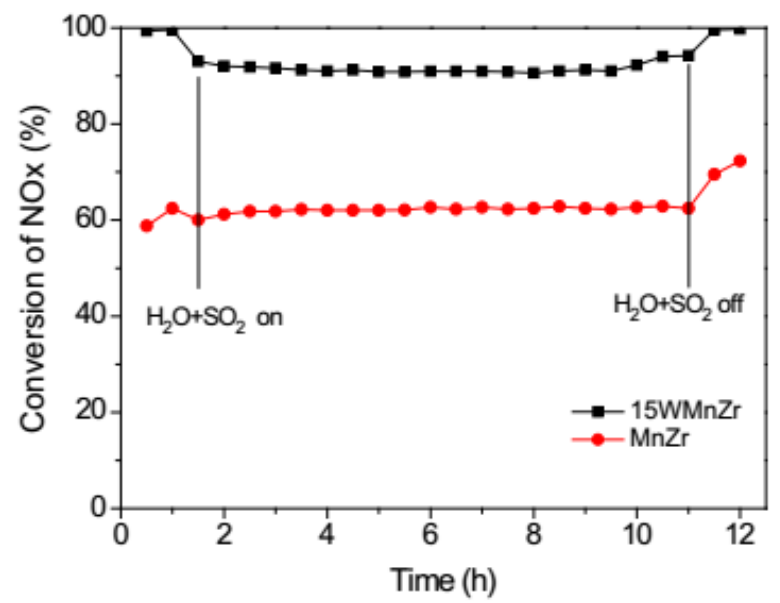

Figure 17. Response of $\mathrm{NO}_{x}$ conversion over $\mathrm{MnZr}$ and $15 \mathrm{WMnZr}$ catalysts at $300{ }^{\circ} \mathrm{C}$ to intermittent feed of $\mathrm{H}_{2} \mathrm{O}$ and $\mathrm{SO}_{2}$ (Reaction conditions: [NO] = $\left[\mathrm{NH}_{3}\right]=500 \mathrm{ppm},\left[\mathrm{O}_{2}\right]=5 \%,\left[\mathrm{H}_{2} \mathrm{O}\right]=5 \%$, $\left[\mathrm{SO}_{2}\right]=50 \mathrm{ppm}, \mathrm{GHSV}=128,000 \mathrm{~h}^{-1}$ ). (Reproduced with permission from Reference [40], Copyright 2016, Elsevier).

\subsection{Supported Mn-Based Catalysts}

Supports play an important role in $\mathrm{NH}_{3}-\mathrm{SCR}$ reaction. Proper supports not only can provide a huge surface to disperse the active components and prevent the formation of large crystalline particles but can also affect the sulfur and water tolerance. To date, various materials, such as $\mathrm{TiO}_{2}$, carbon materials, and $\mathrm{Al}_{2} \mathrm{O}_{3}$, have been explored as supports to load Mn-based catalysts.

\subsection{1. $\mathrm{TiO}_{2}$ Supported Mn-Based Catalysts}

$\mathrm{TiO}_{2}$ is known to be more resistant to sulfur poisoning because of the stability of sulfates on the $\mathrm{TiO}_{2}$ surface is weaker than that on other oxides [59], which made $\mathrm{TiO}_{2}$ an ideal support for the loading of Mn-based catalysts.

Qi and Yang [41] prepared a series of MnTi and FeMnTi catalysts. As shown in Figure 18, the $\mathrm{NO}$ conversion over $\mathrm{Fe}-\mathrm{Mn} / \mathrm{TiO}_{2}$ was decreased from 100 to $90 \%$ within $5 \mathrm{~h}$ at $150{ }^{\circ} \mathrm{C}$ after $100 \mathrm{ppm} \mathrm{SO}_{2}$ and $2.5 \% \mathrm{H}_{2} \mathrm{O}$ were added. After the supply of $\mathrm{SO}_{2}$ and $\mathrm{H}_{2} \mathrm{O}$ was cut off, the $\mathrm{NO}$ 
conversion recovered to $100 \%$ again quickly. Yang et al. investigated the sulfur and water tolerance of Fe-Ti spinel supported $\mathrm{MnO}_{\mathrm{x}}$ catalyst [42]. As shown in Figure 19, the $\mathrm{NO}_{\mathrm{x}}$ conversion at $200{ }^{\circ} \mathrm{C}$ gradually decreased from 100 to $83 \%$ and then kept unchanged after $8 \%$ of $\mathrm{H}_{2} \mathrm{O}$ and $60 \mathrm{ppm}$ of $\mathrm{SO}_{2}$ were introduced. After the supply $\mathrm{H}_{2} \mathrm{O}$ and $\mathrm{SO}_{2}$ was shut off, the $\mathrm{NO}_{x}$ conversion rapidly recovered to $100 \%$. Wu et al. found that the sulfur resistance of $\mathrm{Mn} / \mathrm{TiO}_{2}$ can be greatly improved by Ce addition [9]. As displayed in Figure 20, $\mathrm{SO}_{2}$ presented an obvious poisonous effect on $\mathrm{SCR}$ activity of $\mathrm{Mn} / \mathrm{TiO}_{2}$ at low temperatures because the NO conversion over the MnTi catalyst decreased from 93 to $30 \%$ in the presence of $\mathrm{SO}_{2}$ within $6.5 \mathrm{~h}$, while the $\mathrm{NO}$ conversion over MnCeTi still maintained at about $84 \%$ under the same conditions. As shown in Figure 21, the surface of fresh catalysts was smooth and uniform (Figure 21A,C). After the catalyst was poisoned with $100 \mathrm{ppm} \mathrm{SO}_{2}$ for $24 \mathrm{~h}$, the significant agglomeration and deposition could be observed from the surface of MnTi-S (Figure 21B), while only a few deposited particles (no agglomeration) appeared on the surface of MnCeTi-S (Figure 21D). $\mathrm{Yu}$ et al. [80] developed a mesoporous $\mathrm{MnO}_{2}-\mathrm{Fe}_{2} \mathrm{O}_{3}-\mathrm{CeO}_{2} / \mathrm{TiO}_{2}$ catalyst. The $\mathrm{NO}$ conversion over this catalyst was stable at $80 \%$ under astream of $\mathrm{SO}_{2}$. Shen et al. [43] found that the addition of proper iron enhanced the tolerance of $\mathrm{TiO}_{2}$-supported $\mathrm{Mn}$-Ce catalyst to water and sulfur. As exhibited in Figure 22, $\mathrm{Fe}(0.15)-\mathrm{Mn}-\mathrm{Ce} / \mathrm{TiO}_{2}$ showed higher resistance under $3 \mathrm{vol} \% \mathrm{H}_{2} \mathrm{O}$ and $0.01 \mathrm{vol} \% \mathrm{SO}_{2}$ and still provided $83.8 \% \mathrm{NO}$ conversion over afurther $5 \mathrm{~h}$, an improvement over the $\mathrm{Mn}-\mathrm{Ce} / \mathrm{TiO}_{2}$ catalyst. Shen et al. found that titanium-pillared clays (Ti-PILCs) presented advantages in sulfur tolerance over traditional $\mathrm{TiO}_{2}$ supports [44]. It can be seen from Figure 23 that the $\mathrm{NO}$ conversion was stable at around $90 \%$ without any obvious decrease in the presence of 3 vol $\% \mathrm{H}_{2} \mathrm{O}$ and $0.01 \mathrm{vol} \% \mathrm{SO}_{2}$, suggesting that $\mathrm{Mn}-\mathrm{CeO}_{\mathrm{x}} / \mathrm{Ti}-\mathrm{PILC}(\mathrm{S})$ possessed good resistance to $\mathrm{H}_{2} \mathrm{O}$ and $\mathrm{SO}_{2}$. Lee et al. prepared a series of $\mathrm{Mn} / \mathrm{Ce}-\mathrm{TiO}_{2}$ catalysts and found that $\mathrm{Mn}(20) / \mathrm{Ce}(4)-\mathrm{TiO}_{2}$ showed good $\mathrm{H}_{2} \mathrm{O}$ and $\mathrm{SO}_{2}$ tolerance [45]. As shown in Figure 24, the NO conversion decreased to $60 \%$ and it recovered to almost the original level when the $\mathrm{SO}_{2}$ supply was shut off. Park et al. [83] prepared Mn/Ti catalysts via chemical vapor condensation (CVC) method and claimed that this Mn/Ti not only showed higher activity at low temperature but also exhibited better tolerance to water and sulfur. Only a small $\mathrm{NO}$ conversion decrease from 70 to $58 \%$ was found under $200 \mathrm{ppm}$ of $\mathrm{SO}_{2}$ in $250 \mathrm{~min}$ at $100{ }^{\circ} \mathrm{C}$. Liu et al. [46] prepared an $\mathrm{Mn}-\mathrm{Ce}-\mathrm{Ti}$ catalyst using the hydrothermal method, and the $\mathrm{NO}_{\mathrm{x}}$ conversion over the $\mathrm{Mn}_{0.2} \mathrm{Ce}_{0.1} \mathrm{Ti}_{0.7} \mathrm{O}_{x}$ catalyst under $\mathrm{H}_{2} \mathrm{O}$ and $\mathrm{SO}_{2}$ was further investigated at $200{ }^{\circ} \mathrm{C}$. As shown in Figure 25, the introduction of $\mathrm{H}_{2} \mathrm{O}$ and $\mathrm{SO}_{2}$ induced a slight decrease in $\mathrm{NO}_{\mathbf{x}}$ conversion. After $\mathrm{H}_{2} \mathrm{O}$ and $\mathrm{SO}_{2}$ were excluded from the reactant feed, the $\mathrm{NO}_{x}$ conversion completely recovered.

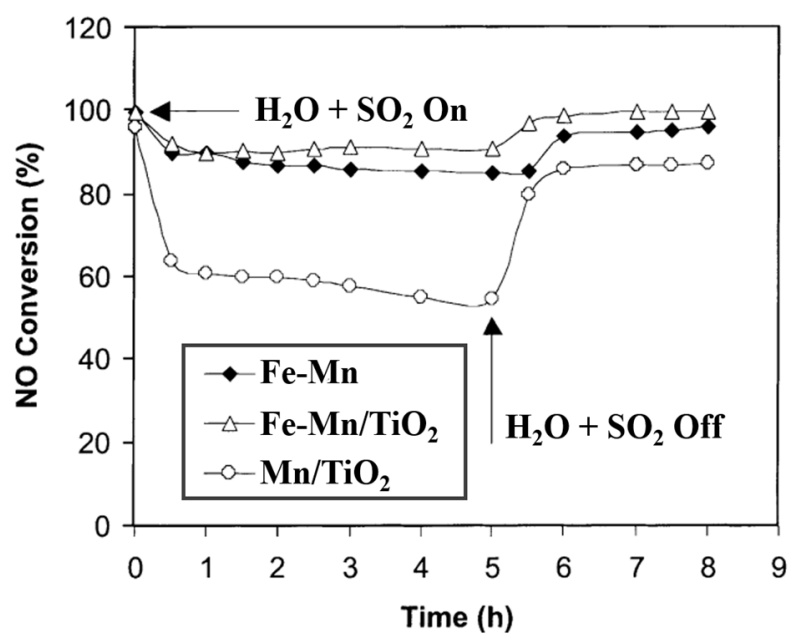

Figure 18. $\mathrm{NO}$ conversion on the various $\mathrm{Fe}-\mathrm{Mn}$-based catalyst in the presence of $\mathrm{SO}_{2}+\mathrm{H}_{2} \mathrm{O}$ (Reaction conditions: temperature $=150{ }^{\circ} \mathrm{C},[\mathrm{NO}]=\left[\mathrm{NH}_{3}\right]=1000 \mathrm{ppm},\left[\mathrm{O}_{2}\right]=2 \%,\left[\mathrm{SO}_{2}\right]=100 \mathrm{ppm}$, $\left[\mathrm{H}_{2} \mathrm{O}\right]=2.5 \%$, balance $\mathrm{He}$, total flow rate $100 \mathrm{~mL} / \mathrm{min}$, catalyst $0.5 \mathrm{~g}$ ). (Reproduced with permission from Reference [41], Copyright 2003, Elsevier). 


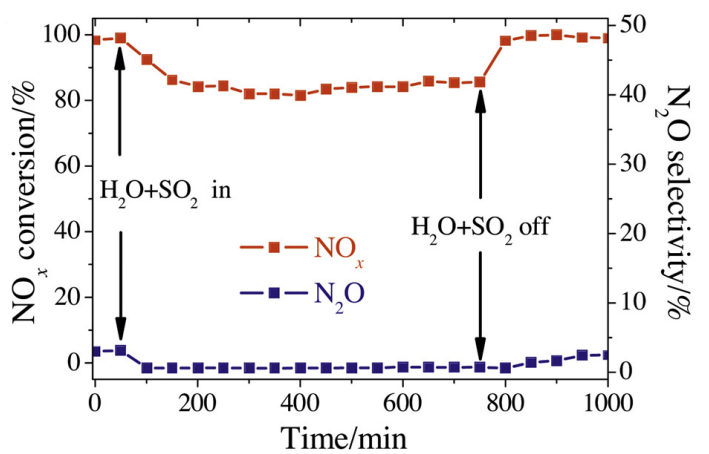

Figure 19. Stability of $\mathrm{NO}$ reduction over $10 \% \mathrm{Mn} / \mathrm{Fe}-\mathrm{Ti}$ spinel in the presence of $\mathrm{H}_{2} \mathrm{O}$ and $\mathrm{SO}_{2}$ (Reaction conditions: $\left[\mathrm{NH}_{3}\right]=[\mathrm{NO}]=500 \mathrm{ppm},\left[\mathrm{SO}_{2}\right]=60 \mathrm{ppm},\left[\mathrm{H}_{2} \mathrm{O}\right]=8 \%$, catalyst mass $=500 \mathrm{mg}$, the total flow rate $=100 \mathrm{~mL}$ and GHSV $=12000 \mathrm{~cm}^{3} \mathrm{~g}^{-1} \mathrm{~h}^{-1}$ ). (Reproduced with permission from Reference [42], Copyright 2016, Elsevier).

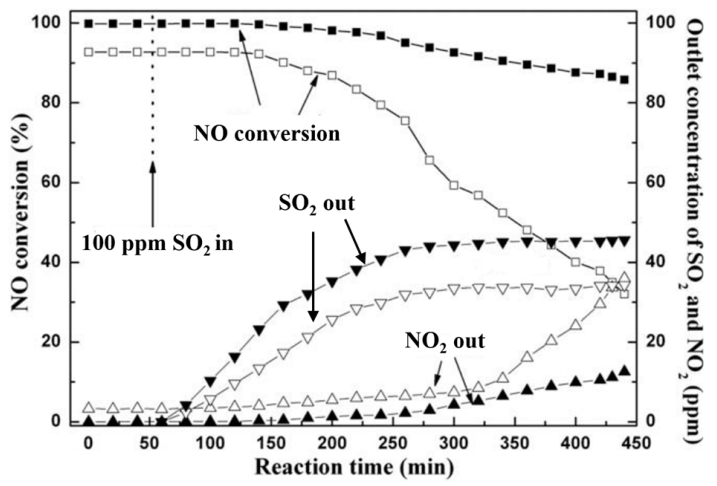

Figure 20. SCR activities of $\mathrm{Mn} / \mathrm{TiO}_{2}$ and Ce-doped $\mathrm{Mn} / \mathrm{TiO}_{2}$ in the presence of $\mathrm{SO}_{2}$ (Reaction conditions: $\left[\mathrm{NH}_{3}\right]=[\mathrm{NO}]=1000 \mathrm{ppm},\left[\mathrm{O}_{2}\right]=3 \%,\left[\mathrm{SO}_{2}\right]=100 \mathrm{ppm},\left[\mathrm{H}_{2} \mathrm{O}\right]=3$ vol \%, $\mathrm{N}_{2}$ balance, GHSV $=40,000 \mathrm{~h}^{-1}$, reaction temperature $=150{ }^{\circ} \mathrm{C}$; hollow symbols for MnTi and solid symbols for MnCeTi).
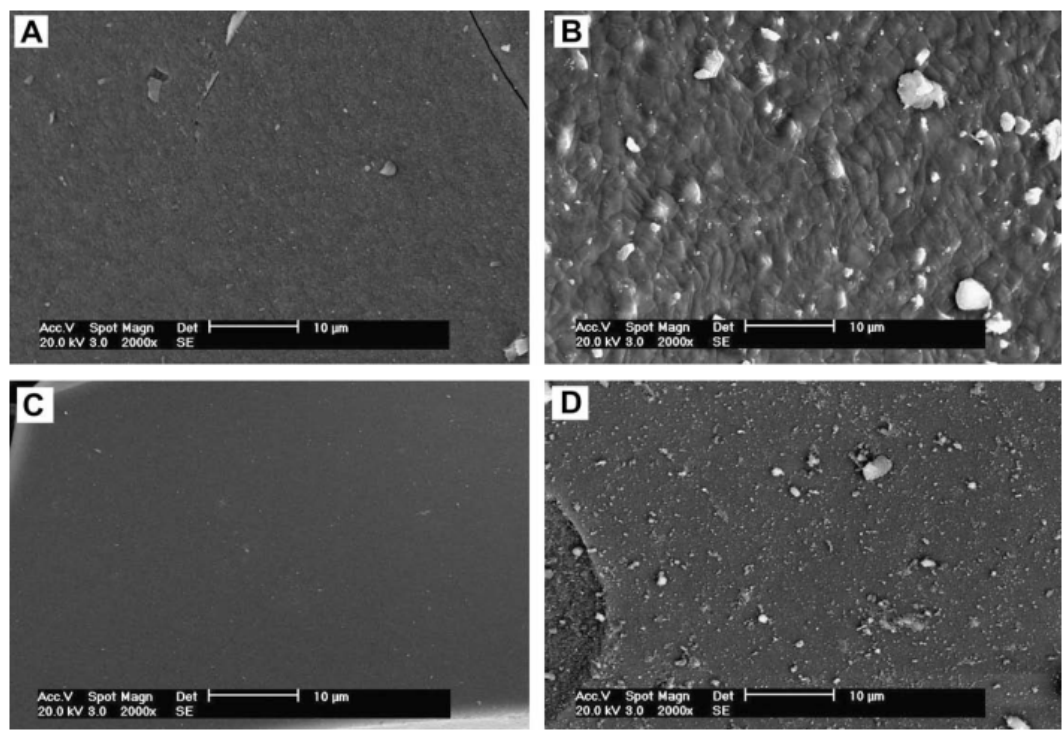

Figure 21. Scanning electron microscope (SEM) micrographs of fresh and $\mathrm{SO}_{2}$-poisoned catalysts. (A) MnTi, (B) MnTi-S, (C) MnCeTi, and (D) MnCeTi-S. (Reproduced with permission from Reference [9], Copyright 2009, Elsevier). 


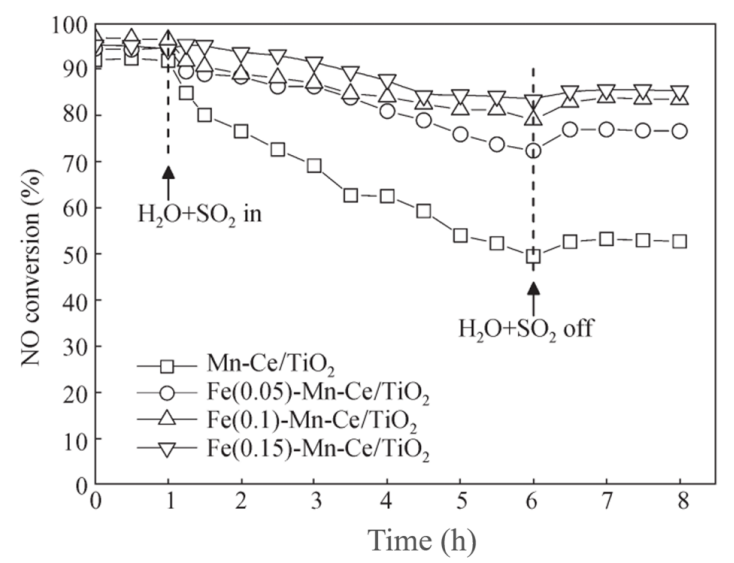

Figure 22. Effect of $\mathrm{H}_{2} \mathrm{O}$ and $\mathrm{SO}_{2}$ on $\mathrm{NO}$ conversion over $\mathrm{Mn}-\mathrm{Ce} / \mathrm{TiO}_{2}$ and $\mathrm{Fe}-\mathrm{Mn}-\mathrm{Ce} / \mathrm{TiO}_{2}$ catalysts (Reaction conditions: $0.06 \mathrm{vol} \% \mathrm{NO}, 0.06 \mathrm{vol} \% \mathrm{NH}_{3}, 3 \mathrm{vol} \% \mathrm{O}_{2}, 3 \mathrm{vol} \% \mathrm{H}_{2} \mathrm{O}$ (when used), $0.01 \mathrm{vol} \%$ $\mathrm{SO}_{2}$ (when used), balance $\mathrm{N}_{2}$, GHSV $50,000 \mathrm{~h}^{-1}$, total flow rate $300 \mathrm{~mL} / \mathrm{min}$, tested at $180{ }^{\circ} \mathrm{C}$ ). (Reproduced with permission from Reference [43], Copyright 2010, Science Direct).

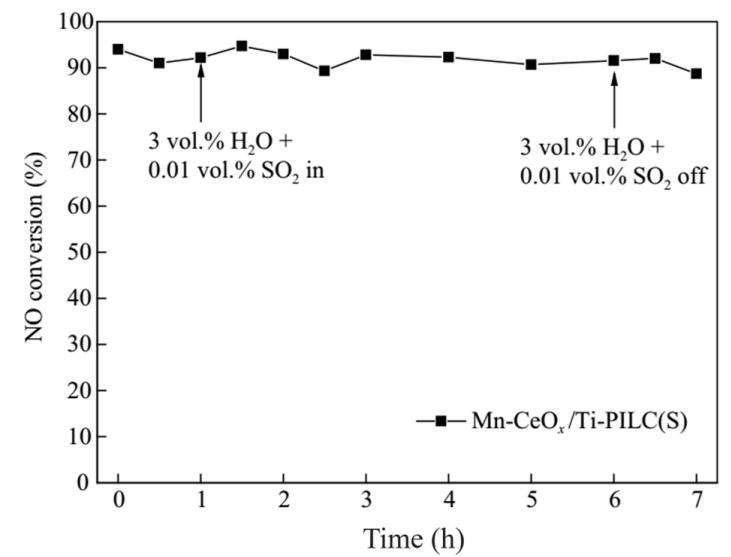

Figure 23. Effect of $\mathrm{H}_{2} \mathrm{O}$ and $\mathrm{SO}_{2}$ on $\mathrm{NO}$ conversion over $\mathrm{Mn}-\mathrm{CeO}_{\mathrm{x}} / \mathrm{TiPILC}(\mathrm{S})$ at $200{ }^{\circ} \mathrm{C}$ (Reaction conditions: $0.06 \mathrm{vol} \% \mathrm{NO}, 0.06 \mathrm{vol} \% \mathrm{NH}_{3}, 3 \mathrm{vol} \% \mathrm{O}_{2}, 3$ vol \% $\mathrm{H}_{2} \mathrm{O}$ (when used), $0.01 \mathrm{vol} \% \mathrm{SO}_{2}$ (when used), balance $\mathrm{N}_{2}$, GHSV 50,000 $\mathrm{h}^{-1}$, total flow rate $300 \mathrm{~mL} / \mathrm{min}$ ). (Reproduced with permission from Reference [44], Copyright 2012, Science Direct).

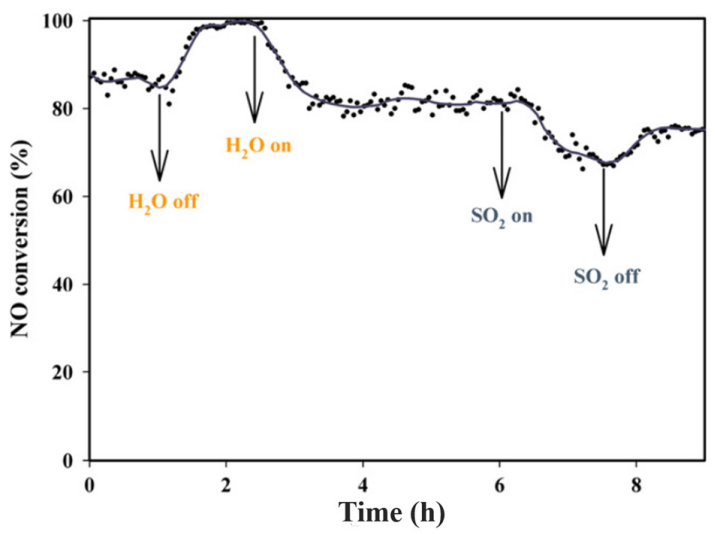

Figure 24. The effects of the $\mathrm{H}_{2} \mathrm{O}$ and $\mathrm{SO}_{2}$ in the $\mathrm{Mn} / \mathrm{Ce}(4)-\mathrm{TiO}_{2}$ catalysts with different ratio of $\mathrm{Ce} / \mathrm{Ti}$ (Reaction condition: $200 \mathrm{ppm} \mathrm{NO}, 8 \% \mathrm{O}_{2}, 6 \% \mathrm{H}_{2} \mathrm{O}, 100 \mathrm{ppm} \mathrm{SO}, 0.28 \mathrm{~g}$ of sample and $500 \mathrm{cc} / \mathrm{min}$ total flow rate, tested at $180^{\circ} \mathrm{C}$ ). (Reproduced with permission from Reference [45], Copyright 2012, Elsevier). 


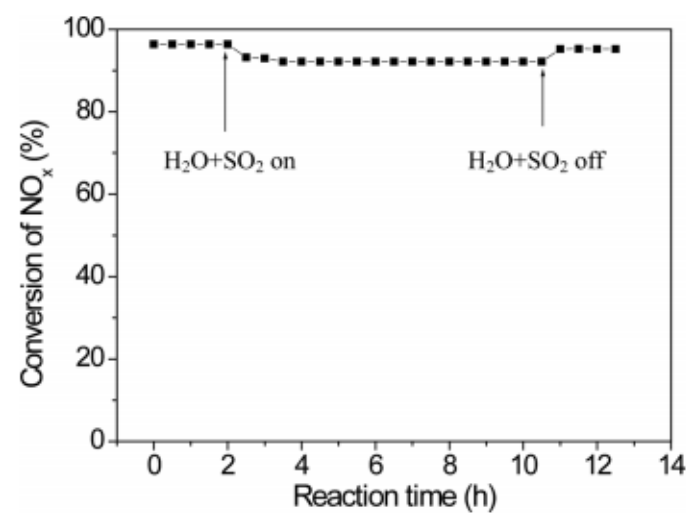

Figure 25. Response of the $\mathrm{NO}_{x}$ conversion over $\mathrm{Mn}_{0.2} \mathrm{Ce}_{0.1} \mathrm{Ti}_{0.7} \mathrm{O}_{\mathrm{x}}$ catalyst at $200{ }^{\circ} \mathrm{C}$ to the intermittent feed of $\mathrm{H}_{2} \mathrm{O}$ and $\mathrm{SO}_{2}$ (Reaction condition: 500 ppm of $\mathrm{NO}, 500 \mathrm{ppm}$ of $\mathrm{NH}_{3}, 5 \% \mathrm{O}_{2}, 5 \% \mathrm{H}_{2} \mathrm{O}$, $50 \mathrm{ppm}$ of $\mathrm{SO}_{2}$, balance $\mathrm{He}, \mathrm{GHSV}=64,000 \mathrm{~h}^{-1}$ ). (Reproduced with permission from Reference [46], Copyright 2014, American Chemical Society).

\subsubsection{Carbon Materials Supported Mn-Based Catalysts}

Carbon materials, such as activated carbon (AC), activated carbon fiber (ACF), carbon nanotube (CNT), and graphene (GE), have been widely studied as substrates for supporting low-temperature SCR catalysts due to their high specific surface area, unique pore structure, excellent dispersion of active components, and chemical stability [70,84-86]. Among these carbon materials, CNT and GE have been considered as good supports that can enhance the tolerance of $\mathrm{H}_{2} \mathrm{O}$ and $\mathrm{SO}_{2}$.

Zhang et al. prepared a novel MnCe@CNTs-R catalyst, which exhibited great tolerance to $100 \mathrm{ppm}$ $\mathrm{SO}_{2}$ and $4 \mathrm{vol} \% \mathrm{H}_{2} \mathrm{O}$ due to the good dispersion degree of the active components on the surface of CNTs [48]. The coexistence of $\mathrm{SO}_{2}$ and $\mathrm{H}_{2} \mathrm{O}$ induced a $13 \% \mathrm{NO}$ conversion decrease and the $\mathrm{NO}$ conversion was recovered to $90 \%$ after the supply of $\mathrm{SO}_{2}$ and $\mathrm{H}_{2} \mathrm{O}$ was cut off. Cai et al. designed a multi-shell $\mathrm{Fe}_{2} \mathrm{O}_{3} @ \mathrm{MnO}_{\mathrm{x}} @ \mathrm{CNTs}$ catalyst and found that the $\mathrm{Fe}_{2} \mathrm{O}_{3}$ shell effectively suppressed the formation of the surface sulfate species, which led to a good tolerance to $\mathrm{H}_{2} \mathrm{O}$ and $\mathrm{SO}_{2}$ (Figure 26) [49]. $\mathrm{Lu}$ et al. successfully synthesized a series of $\mathrm{TiO}_{2}$-graphene-supported $\mathrm{Mn}$ and $\mathrm{Mn}-\mathrm{Ce}$ catalysts with good tolerance to $\mathrm{H}_{2} \mathrm{O}$ and $\mathrm{SO}_{2}$ due to the well dispersed Mn component (Figure 27) [50,51]. Wang et al. investigated the effect of $\mathrm{SO}_{2}$ on activated carbon honeycomb ( $\mathrm{ACH}$ )-supported $\mathrm{MnO}_{x}$ and $\mathrm{CeO}_{2}-\mathrm{MnO}_{\mathrm{x}}$ catalysts, and the S 2p XPS results are displayed in Figure 28. The peak intensity of $\mathrm{Mn} / \mathrm{ACH}$ was much higher than that of $\mathrm{CeMn} / \mathrm{ACH}$, indicating that Ce doping on $\mathrm{ACH}$ had an inhibition of sulfates loading [81].

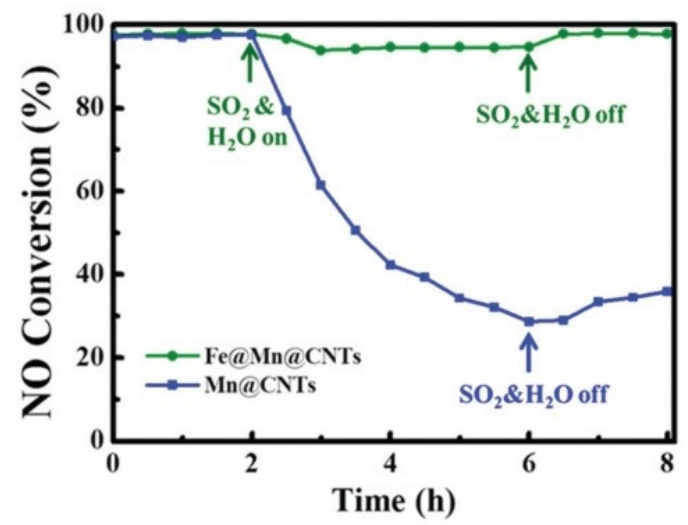

Figure 26. $\mathrm{SO}_{2}+\mathrm{H}_{2} \mathrm{O}$ tolerance test at $240{ }^{\circ} \mathrm{C}$ (Reaction conditions: $\left[\mathrm{NH}_{3}\right]=[\mathrm{NO}]=550 \mathrm{ppm}$, $\left[\mathrm{O}_{2}\right]=5 \mathrm{vol} \%,\left[\mathrm{SO}_{2}\right]=100 \mathrm{ppm},\left[\mathrm{H}_{2} \mathrm{O}\right]=10 \mathrm{vol} \%$ (when used), $\mathrm{N}_{2}$ as balance gas, GHSV = 20,000 $\mathrm{h}^{-1}$ ). (Reproduced with permission from Reference [49], Copyright 2016, The Royal Society of Chemistry). 


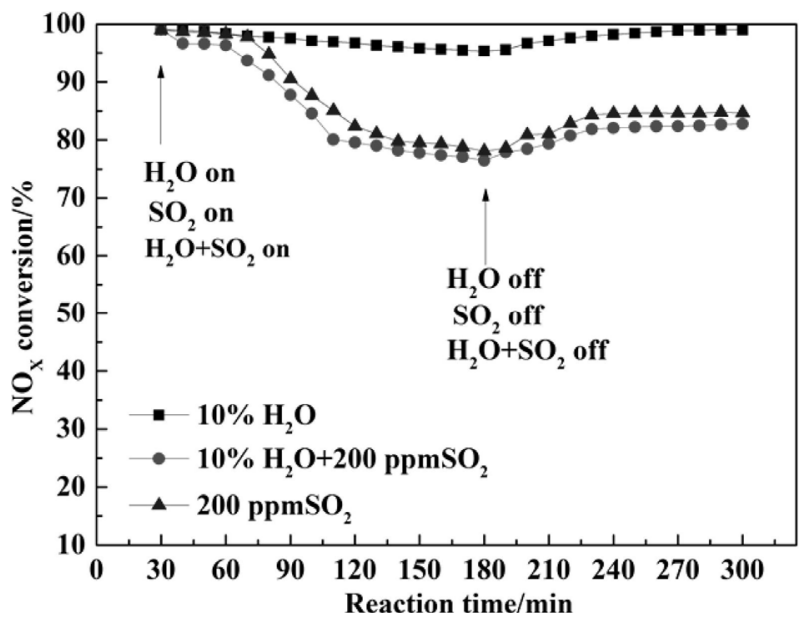

Figure 27. $\mathrm{SO}_{2}+\mathrm{H}_{2} \mathrm{O}$ tolerance test at $180{ }^{\circ} \mathrm{C}$ (Reaction conditions: $\left[\mathrm{NH}_{3}\right]=[\mathrm{NO}]=500 \mathrm{ppm}$, $\left[\mathrm{O}_{2}\right]=7 \mathrm{vol} \%,\left[\mathrm{SO}_{2}\right]=200 \mathrm{ppm},\left[\mathrm{H}_{2} \mathrm{O}\right]=10 \mathrm{vol} \%$ (when used), $\mathrm{N}_{2}$ as balance gas, GHSV $=67,000 \mathrm{~h}^{-1}$ ). (Reproduced with permission from Reference [51], Copyright 2015, Elsevier).

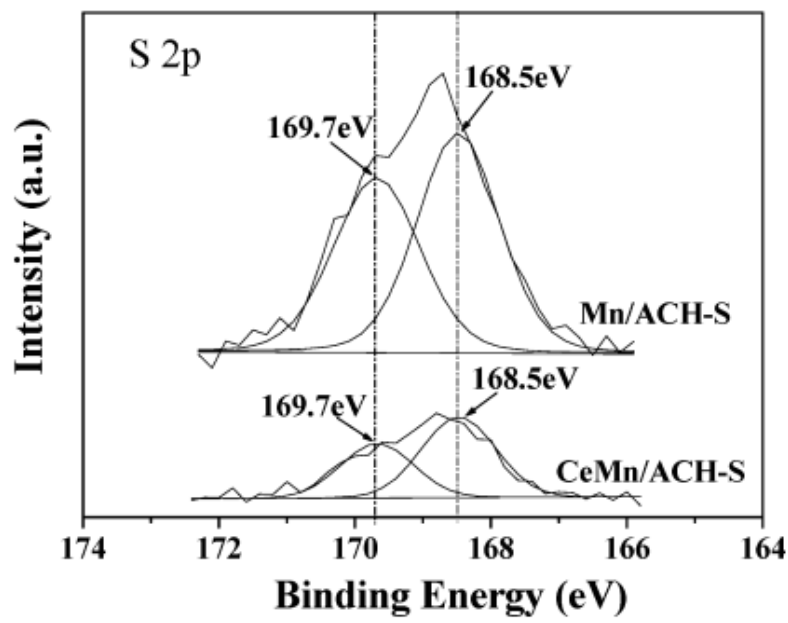

Figure 28. X-ray photoelectron spectroscopy (XPS) spectra of S $2 p$ for poisoned $\mathrm{Mn} / \mathrm{ACH}$ and $\mathrm{CeMn} / \mathrm{ACH}$ catalysts. (Reproduced with permission from Reference [81], Copyright 2015, American Chemical Society).

\subsubsection{Other Supported Mn-Based Catalysts}

Mixed metal oxides and $\mathrm{SiO}_{2}$ have also been studied as substrates for supporting SCR catalysts. Yao et al. prepared $\mathrm{MnO}_{\mathrm{x}} / \mathrm{SiO}_{2}, \mathrm{MnO}_{\mathrm{x}} / \mathrm{Al}_{2} \mathrm{O}_{3}, \mathrm{MnO}_{\mathrm{x}} / \mathrm{TiO}_{2}$, and $\mathrm{MnO}_{\mathrm{x}} / \mathrm{CeO}_{2}$ catalysts and found that the catalytic activity in the presence of $\mathrm{H}_{2} \mathrm{O}$ and $\mathrm{SO}_{2}$ was in the order of $\mathrm{MnO}_{\mathrm{x}} / \mathrm{SiO}_{2}<\mathrm{MnO}_{\mathrm{x}} / \mathrm{TiO}_{2}<\mathrm{MnO}_{\mathrm{x}} / \mathrm{CeO}_{2}<\mathrm{MnO}_{\mathrm{x}} / \mathrm{Al}_{2} \mathrm{O}_{3}$ (Figure 29) [87]. Shen et al. also compared the tolerance to $\mathrm{H}_{2} \mathrm{O}$ and $\mathrm{SO}_{2}$ of $\mathrm{MnO}_{\mathrm{x}}$-supported on various substrates including $\mathrm{Al}_{2} \mathrm{O}_{3}, \mathrm{TiO}_{2}, \mathrm{CeO}_{2}$, $\mathrm{ZrO}_{2}$, and $\mathrm{Ce}_{0.5} \mathrm{Zr}_{0.5} \mathrm{O}_{2}$. Their results showed that the resistance ability was decreased in the following order: $\mathrm{MnO}_{\mathrm{x}} / \mathrm{Ce}_{0.5} \mathrm{Zr}_{0.5} \mathrm{O}_{2}>\mathrm{MnO}_{\mathrm{x}} / \mathrm{Al}_{2} \mathrm{O}_{3}>\mathrm{MnO}_{\mathrm{x}} / \mathrm{CeO}_{2}>\mathrm{MnO}_{\mathrm{x}} / \mathrm{TiO}_{2}>\mathrm{MnO}_{\mathrm{x}} / \mathrm{ZrO}_{2}$, and they ascribed the excellent toleranceof $\mathrm{MnO}_{\mathrm{x}} / \mathrm{Ce}_{0.5} \mathrm{Zr}_{0.5} \mathrm{O}_{2}$ to the combination of the advantages of the two supports $\left(\mathrm{ZrO}_{2}\right.$ and $\left.\mathrm{CeO}_{2}\right)$ (Figure 30) [52]. Huang et al. prepared a mesoporous silica-supported $\mathrm{Mn}-\mathrm{Fe}$ catalyst and found that its SCR activity was suppressed gradually in the presence of $\mathrm{SO}_{2}$ and $\mathrm{H}_{2} \mathrm{O}$, and the inhibitory effect was relieved after heating treatment [88]. 


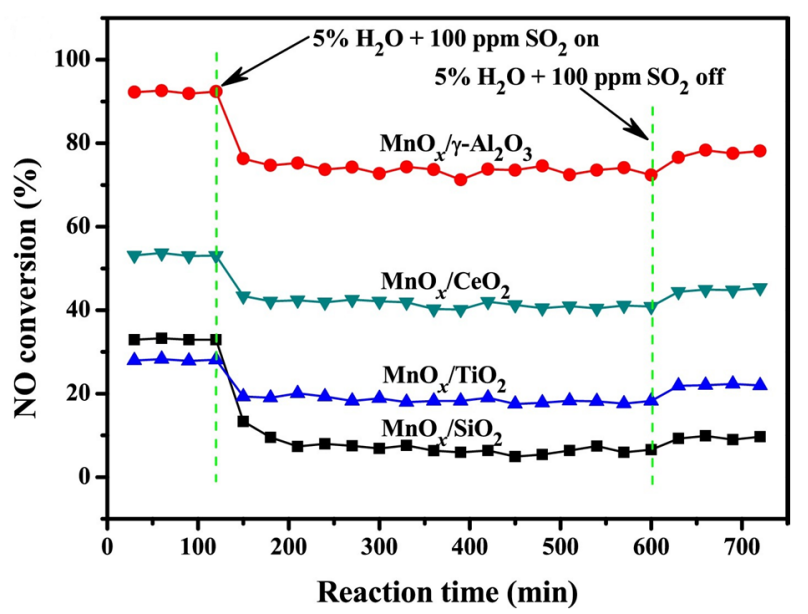

Figure 29. The results of $\mathrm{H}_{2} \mathrm{O}+\mathrm{SO}_{2}$ resistance at $200{ }^{\circ} \mathrm{C}$ of these supported Mn-based catalysts with different supports. (Reproduced with permission from Reference [87], Copyright 2017, Elsevier).

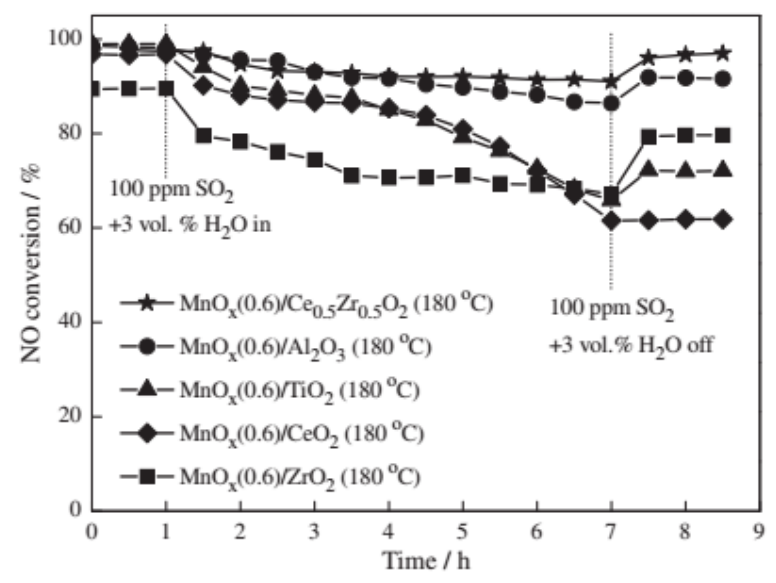

Figure 30. The effect of $\mathrm{H}_{2} \mathrm{O}$ and $\mathrm{SO}_{2}$ on $\mathrm{NO}$ conversion for $\mathrm{MnO}_{\mathrm{x}}(0.6) / \mathrm{Ce}_{0.5} \mathrm{Zr}_{0.5} \mathrm{O}_{2}$ (Reaction conditions: $[\mathrm{NO}]=\left[\mathrm{NH}_{3}\right]=600 \mathrm{ppm},\left[\mathrm{O}_{2}\right]=3 \mathrm{vol} \%, \mathrm{~N}_{2}$ balance, $\mathrm{T}=180^{\circ} \mathrm{C}$, catalyst $0.5 \mathrm{~g}$, GHSV 30,000 $\mathrm{h}^{-1}$ ). (Reproduced with permission from Reference [52], Copyright 2014, Elsevier).

\section{Strategies to Reduce the Poisoning Effect}

Although there are many factors that affect the water and sulfur tolerance of Mn-based catalysts, such as the preparation method, the reaction temperature, the gas hourly space velocity (GHSV), and the morphology, structure, and surface area of the catalyst, deactivation can be attributedto three main causes: (1) the competitive adsorption between $\mathrm{SO}_{2}$ and $\mathrm{NO}, \mathrm{H}_{2} \mathrm{O}$, and $\mathrm{NH}_{3}$ on the active sites, (2) the blocking effect of the $\mathrm{NH}_{4} \mathrm{HSO}_{4}$ and $\left(\mathrm{NH}_{4}\right)_{2} \mathrm{SO}_{4}$ formed on the surface active sites, and (3) the formation of metallic sulfate, which reduces the active sites on the surface. Hence, suppressing the three negative effects is the key to enhancing resistance against $\mathrm{H}_{2} \mathrm{O}$ and $\mathrm{SO}_{2}$. To date, many strategies have been taken to reduce the poisoning effect on Mn-based catalysts.

\subsection{Metal Modification}

Metal modification or doping is a common solution to the problem. Most transition metals have been used as dopants to modify Mn-based catalysts for good resistance to $\mathrm{SO}_{2}$ and $\mathrm{H}_{2} \mathrm{O}$. Cerium has been fully studied, and the mechanism has been uncovered. Cerium reacts more sensitively with $\mathrm{SO}_{2}$, so the formation of $\mathrm{NH}_{4} \mathrm{HSO}_{4}$ and $\left(\mathrm{NH}_{4}\right)_{2} \mathrm{SO}_{4}$ is reduced on the surface of Ce-modified Mn-based catalysts $[36,79,89]$. Furthermore, metallic sulfates formed by cerium and $\mathrm{SO}_{2}$ are relatively 
stable and can provide surface acid sites to enhance the adsorption of $\mathrm{NH}_{3}$ and to inhibit the catalytic oxidization of $\mathrm{NH}_{3}$ at the same time, thus promoting SCR reactions in the presence of $\mathrm{SO}_{2}$ and $\mathrm{H}_{2} \mathrm{O}[68,78,90]$. Liu et al. confirmed, using density functional theory, that Ce isable to inhibit the formation of ammonia sulfate on the surface of catalysts, which is believed to be a key factor in improving tolerance [79]. It was also reported that iron is capable of decreasing the formation rate of sulfate species, thus promoting tolerance [41,91]. Furthermore, several reports have shown that the doping of a third metal, such as $\mathrm{Sn}$ and $\mathrm{W}$, into Mn-based catalysts can further improve resistance to $\mathrm{SO}_{2}$ and $\mathrm{H}_{2} \mathrm{O}[38,92,93]$. Zhang et al. found that resistance to $\mathrm{SO}_{2}$ and $\mathrm{H}_{2} \mathrm{O}$ over the $\mathrm{W}$-modified $\mathrm{SnMnCeO}_{\mathrm{x}}$ catalysts, in comparison with unmodified $\mathrm{SnMnCeO}_{\mathrm{x}}$, was further improved (Figure 31) [53]. They attributed this improvement to the introduction of $\mathrm{WO}_{\mathrm{x}}$ species, which prevented the formation of $\left(\mathrm{NH}_{4}\right)_{2} \mathrm{SO}_{4}$ on the catalyst and blocked the interactions between $\mathrm{Mn}^{\mathrm{n}+}, \mathrm{SO}_{4}{ }^{2-}$, and gaseous $\mathrm{SO}_{3}$ [37]. Rare earths have drawn an increasing amount of attention recently, and $\mathrm{Sm}$ and Eu doping have been shown to have a positive influence on the tolerance of $\mathrm{SO}_{2}$ and $\mathrm{H}_{2} \mathrm{O}[33,34]$. However, the mechanism of $\mathrm{SO}_{2}$ and $\mathrm{H}_{2} \mathrm{O}$ resistance still needs to be uncovered.

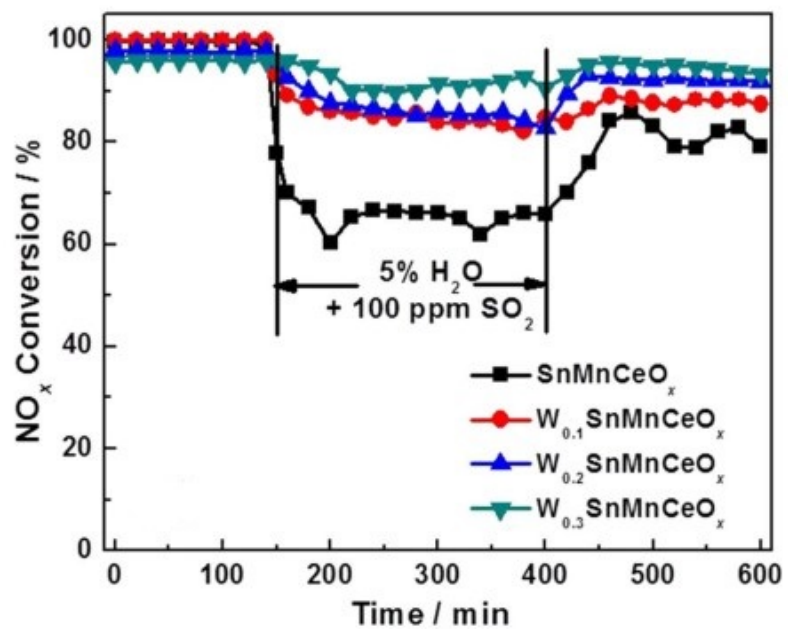

Figure 31. $\mathrm{NH}_{3}-\mathrm{SCR}$ activity over $\mathrm{W}_{\mathrm{y}} \mathrm{SnMnCeO}_{\mathrm{x}}$ catalysts in the presence of $\mathrm{SO}_{2} / \mathrm{H}_{2} \mathrm{O}$ at $200{ }^{\circ} \mathrm{C}$ (Reaction conditions: $[\mathrm{NO}]=\left[\mathrm{NH}_{3}\right]=500 \mathrm{ppm},\left[\mathrm{O}_{2}\right]=5 \%,\left[\mathrm{SO}_{2}\right]=100 \mathrm{ppm}$ (when used), $\left[\mathrm{H}_{2} \mathrm{O}\right]=5 \%$ (when used), $\mathrm{N}_{2}$ balance, total flow rate $100 \mathrm{~mL} \mathrm{~min}^{-1}$ and GHSV $=60,000 \mathrm{mLg}^{-1} \mathrm{~h}^{-1}$ ). (Reproduced with permission from Reference [53], Copyright 2017, Elsevier).

\subsection{Proper Support}

It is well believed that loading Mn-based SCR catalysts on a suitable support is an effective measure to enhance the tolerance to $\mathrm{SO}_{2}$ and $\mathrm{H}_{2} \mathrm{O}[60,94]$ because of the high thermal and mechanical stability, large surface area, and highly dispersed active sites. Furthermore, the interaction between support and active components exhibits positive effects on the tolerance to $\mathrm{SO}_{2}$ and $\mathrm{H}_{2} \mathrm{O}$ [95]. Therefore, it is very important for Mn-based catalysts to choose an appropriate support. Among several supports, $\mathrm{TiO}_{2}$, porous carbon material, and CNTs are considered to be good options. It has been widely reported that $\mathrm{TiO}_{2}$ can provide a higher specific surface area [58], a higher surface acidity [96], and a good dispersion of active components, all of which effectively enhance $\mathrm{SO}_{2}$ and $\mathrm{H}_{2} \mathrm{O}$ resistance [97]. Gao et al. reported a novel nanocomposite of $\mathrm{MnO}_{\mathrm{x}}$ nanoparticles supported on three-dimensionally ordered macroporous carbon $\left(\mathrm{MnO}_{\mathrm{x}} / 3 \mathrm{DOMC}\right)$. They found that this novel catalyst exhibited good water and sulfur tolerance (Figure 32) [54]. As a special ordered carbon material with unique nanostructure and electronic properties, carbon nanotubes (CNTs) have been reported to be an interesting support for SCR catalysts [98,99]. Zhang et al. proved that active components were well dispersed on the surface of the support such that the blocking effect caused by $\mathrm{NH}_{4} \mathrm{HSO}_{4}$ and $\left(\mathrm{NH}_{4}\right)_{2} \mathrm{SO}_{4}$ was reduced [48]. 


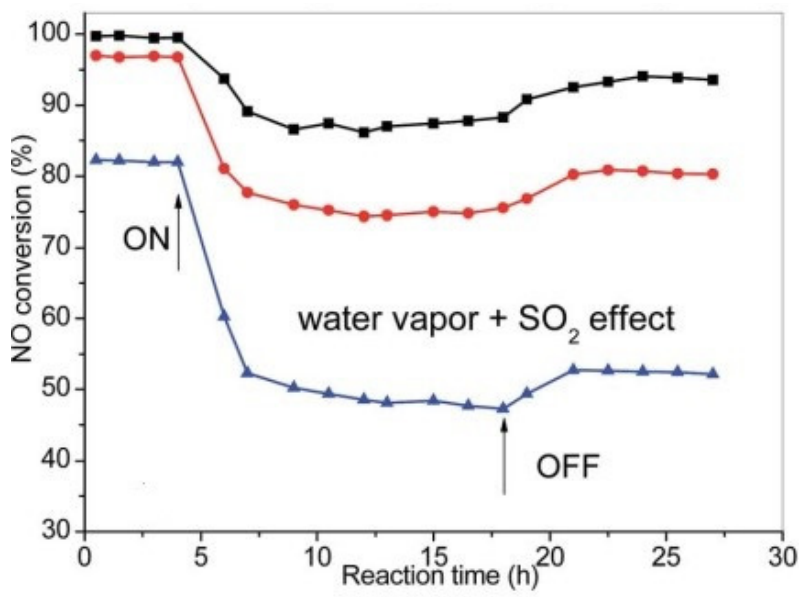

Figure 32. Effect of water vapor and $\mathrm{SO}_{2}$ on $\mathrm{NO}$ conversion over the $\mathrm{MnO}_{\mathrm{x}} / 3 \mathrm{DOMC}$ (black), $\mathrm{MnO}_{\mathrm{x}} / \mathrm{NAC}$ (red), and $\mathrm{MnO}_{\mathrm{x}} / \mathrm{TiO}_{2}$ (blue) catalysts (Reaction conditions: $190{ }^{\circ} \mathrm{C}, 1000 \mathrm{ppm}$ of $\mathrm{NO}$, $1000 \mathrm{ppm}$ of $\mathrm{NH}_{3}, 5 \%$ of $\mathrm{O}_{2}, 5 \%$ of water vapor, and/or $200 \mathrm{ppm}$ of $\mathrm{SO}_{2}$, He balance). (Reproduced with permission from Reference [54] Copyright 2015, The Royal Society of Chemistry).

\subsection{Combination of Metal Modification and Support}

The combination of metal modification and support is considered to be a good way of enhancing the water and sulfur tolerance of Mn-based catalysts due to the advantages of both strategies. Compared with non-supported mixed metal oxides, supported catalysts often possess a larger specific surface area and a better dispersion of active components, which facilitates tolerance to water and sulfur. On the other hand, compared with supported single $\mathrm{MnO}_{\mathrm{x}}$ catalysts, the synergistic effect introduced by one or more modifiers can reduce the poisonous effect and protect the surface active components. Thus, combining two measures, mixing (or doping) $\mathrm{MnO}_{\mathrm{x}}$ with suitable metal oxides and loading active components on a suitable support, is the best way to enhance the tolerance to water and sulfur. Chen et al. prepared an NiMn/Ti catalyst and investigated the effects of $\mathrm{H}_{2} \mathrm{O}$ and $\mathrm{SO}_{2}$ on its SCR performance (Figure 33) [47]. They found that the coexistence of $100 \mathrm{ppm} \mathrm{SO}_{2}$ and $15 \mathrm{vol} \% \mathrm{H}_{2} \mathrm{O}$ led to an apparent decrease in $\mathrm{NO}_{\mathrm{x}}$ conversion, and the $\mathrm{NO}_{\mathrm{x}}$ conversion recovered quickly to $100 \%$ after stopping the addition of $\mathrm{H}_{2} \mathrm{O}$. Chen et al. found that $\mathrm{W}$-modified $\mathrm{MnO}_{\mathrm{x}} / \mathrm{TiO}_{2}$ exhibited better tolerance to $\mathrm{SO}_{2}$ than $\mathrm{MnO}_{\mathrm{x}} / \mathrm{TiO}_{2}$ catalyst due to the fact that $\mathrm{W}$ addition inhibited the formation of sulfate species [93]. Wang et al. reported a series of $\mathrm{W}$-modified $\mathrm{MnO}_{\mathrm{x}} / \mathrm{TiO}_{2}$ and found that a $\mathrm{W}(0.25)-\mathrm{Mn}(0.25)-\mathrm{Ti}(0.5)$ catalyst showed the best SCR activity and good tolerance to water and sulfur. As illustrated in Figure 34, the W(0.25)-Mn(0.25)-Ti(0.5) catalyst presented a 100\% $\mathrm{NO}_{\mathrm{x}}$ conversion from 140 to $260{ }^{\circ} \mathrm{C}$ [55]. Our group successfully prepared a europium-modified $\mathrm{TiO}_{2}$-supported Mn-based catalyst and found that this catalyst showed better tolerance than the $\mathrm{Mn}-\mathrm{TiO}_{2}$ catalyst due to the highly dispersed $\mathrm{MnO}_{\mathrm{x}}$ and $\mathrm{Eu}_{2} \mathrm{O}_{3}$ on the surface of $\mathrm{TiO}_{2}$ [18]. Zhao et al. synthesized an $\mathrm{Nb}$-modified $\mathrm{Mn} / \mathrm{Ce} / \mathrm{Ti}$ catalyst and tested the water and sulfur tolerance at a high GHSV of $180,000 \mathrm{~h}^{-1}$ at $175^{\circ} \mathrm{C}$ [100]. They found that the catalyst was deactivated with a decreased NO conversion from 100 to $10 \%$ within $4 \mathrm{~h}$, which recovered to almost the original level after regeneration by washing. 


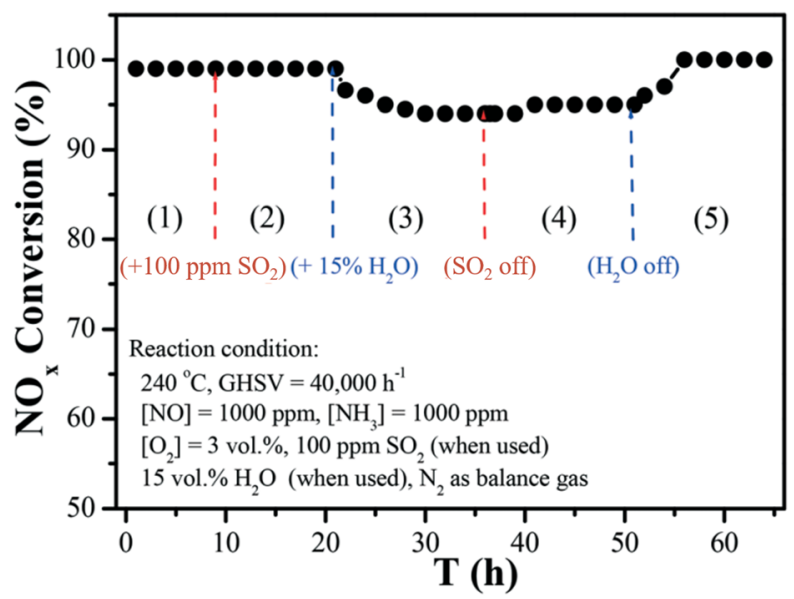

Figure 33. Effects of $\mathrm{H}_{2} \mathrm{O}$ and $\mathrm{SO}_{2}$ on $\mathrm{NO}_{x}$ conversion over the $\mathrm{Ni}_{0.4} \mathrm{Mn}_{0.6} \mathrm{Ti}_{10}$ catalyst. (Reproduced with permission from Reference [47], Copyright 2017, The Royal Society of Chemistry).

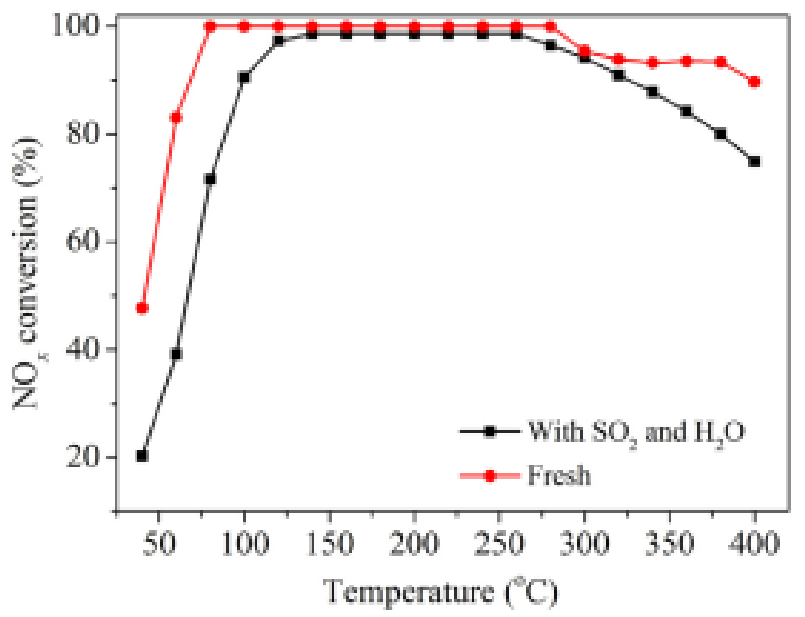

Figure 34. Effects of $\mathrm{SO}_{2}$ and $\mathrm{H}_{2} \mathrm{O}$ on the $\mathrm{NO}_{x}$ conversion of $\mathrm{W}(0.25)-\mathrm{Mn}(0.25)-\mathrm{Ti}(0.5)$ at GHSV of $25,000 \mathrm{~h}^{-1}$ (Reaction conditions: $[\mathrm{NO}]=\left[\mathrm{NH}_{3}\right]=1000 \mathrm{ppm},\left[\mathrm{O}_{2}\right]=5 \mathrm{vol} \%,\left[\mathrm{SO}_{2}\right]=100 \mathrm{ppm}$, $\left[\mathrm{H}_{2} \mathrm{O}\right]=10 \mathrm{vol} \%$, in $\mathrm{He}$ as balance). (Reproduced with permission from Reference [55], Copyright 2016, Elsevier).

\subsection{Rational Design of Structure and Morphology}

The rational design of catalyst structure and morphology is another method of reducing the poisoning effect of $\mathrm{SO}_{2}$ and $\mathrm{H}_{2} \mathrm{O}$. Shen et al. developed a hollow $\mathrm{MnO}_{\mathrm{x}}-\mathrm{CeO}_{2}$ mixed oxide catalyst, which exhibited good SCR performance under water and sulfur poison at a high GHSV of 120,000 $\mathrm{h}^{-1}$ due to the hollow structure [101]. Zhang et al. [28] found that an $\mathrm{Mn}_{\mathrm{x}} \mathrm{Co}_{3-\mathrm{x}} \mathrm{O}_{4}$ catalyst with a nanocage structure exhibited much better $\mathrm{SO}_{2}$ and $\mathrm{H}_{2} \mathrm{O}$ tolerance than $\mathrm{Mn}_{\mathrm{x}} \mathrm{Co}_{3-\mathrm{x}} \mathrm{O}_{4}$ without a nanocage structure. Qiu et al. synthesized a mesoporous $3 \mathrm{D}-\mathrm{MnCo}_{2} \mathrm{O}_{4}$ catalyst that exhibited great $\mathrm{SCR}$ activity and good tolerance to sulfur and water [30,31], and the mesoporous structure enabled a dynamic balance between the formation and decomposition of ammonium sulfate, and thus suppressed the blocking effect during the SCR reaction. Li et al. prepared $\mathrm{Mn}_{2} \mathrm{O}_{3}$-doped $\mathrm{Fe}_{2} \mathrm{O}_{3}$ hexagonal microsheet catalyst [102] and found the single $\mathrm{H}_{2} \mathrm{O}$ resistance $(15 \%)$ and the single $\mathrm{SO}_{2}$ resistance (100 ppm) over this catalyst were good and stable with the NO conversion at around $92 \%$ and $85 \%$ for $100 \mathrm{~h}$, respectively, because of this special structure. 


\subsection{Monolithic Catalysts}

Preparing monolithic catalysts may be an option to promote the tolerance of Mn-based SCR catalysts to $\mathrm{SO}_{2}$ and $\mathrm{H}_{2} \mathrm{O}$. As well known, the commercial catalysts $\left(\mathrm{V}_{2} \mathrm{O}_{5}-\mathrm{WO}_{3}\left(\right.\right.$ or $\left.\left.\mathrm{MoO}_{3}\right) / \mathrm{TiO}_{2}\right)$ used in thermal power plant are in the monolithic form because the honeycomb monoliths are suitable for a high gas flow rate, reduce pressure drop problems, exhibit high tolerance to dust and attrition, and are easy to regenerate [103-106]. Recently, metal foam and wire mesh as novel monolithic support for Mn-based and other vanadium-free SCR catalysts are drawing an increasing amount of attention due to their high porosity, stability, thermal conductivity, and mass transfer ability $[107,108]$. Xu et al. prepared porous $\mathrm{MnCo}_{x} \mathrm{O}_{y}$ nanocubes on a Ti mesh as a novel monolith de- $\mathrm{NO}_{x}$ catalyst for SCR [109]. They found that this monolithic catalyst exhibited better SCR activity than $\mathrm{MnCo}_{\mathrm{x}} \mathrm{O}_{\mathrm{y}} @$ honeycomb ceramics. Meanwhile, the water resistance test results of this novel monolithic catalyst were promising. $\mathrm{Xu}$ et al. successfully synthesized a series of $\mathrm{MnO} \mathrm{x}_{\mathrm{x}}-\mathrm{CeO}_{2} / \mathrm{WO}_{3}-\mathrm{ZrO}_{2}$ monolithic catalysts that showed good tolerance to water and sulfur [110].

\section{Conclusions and Perspectives}

Recent progress on the sulfur and water resistance of Mn-based catalysts for the low-temperature selective catalytic reduction of $\mathrm{NO}_{\mathrm{x}}$ has been reviewed comprehensively in this work. Although much progress has been made, many questions still need to be answered, and many problems need to be solved:

(1) The exploration of novel Mn-based catalysts with excellent resistance to $\mathrm{SO}_{2}$ and $\mathrm{H}_{2} \mathrm{O}$ is still worthwhile. Resistance to $\mathrm{SO}_{2}$ and $\mathrm{H}_{2} \mathrm{O}$ directly decides whether this catalyst can be commercialized. Up to now, mixing (or doping) $\mathrm{MnO}_{\mathrm{x}}$ with suitable metal oxides and loading Mn-based active components on a suitable support are considered an efficient strategy. Discovering new doping elements and novel supports may be promising research directions.

(2) The actual effect of every specific doping element on tolerance promotion needs to be explained. To date, many works have been done to test the tolerance of Mn-based catalysts to $\mathrm{H}_{2} \mathrm{O}$ and $\mathrm{SO}_{2}$. However, the reasons why the tolerance of Mn-based catalysts to $\mathrm{H}_{2} \mathrm{O}$ and $\mathrm{SO}_{2}$ can be enhanced by mixing (or doping) them with other suitable elements need to be further explored in detail.

(3) The role of support ought to be further analyzed. Does support only provide a higher specific surface area and a good dispersion of Mn? Is the support involved in SCR reaction? Such questions need to be answered.

(4) Long-term tolerance tests need to be conducted. Most tests only last for several hours, and it is hard to predict the long-term performance of the catalyst under $\mathrm{H}_{2} \mathrm{O}$ and $\mathrm{SO}_{2}$ poison.

(5) $\mathrm{N}_{2}$ selectivity is an important indicator for the commercialization of SCR catalysts, which is closely related to the yield of $\mathrm{N}_{2} \mathrm{O}$. However, there is currently a lack of research on the effect of $\mathrm{SO}_{2}$ on $\mathrm{N}_{2}$ selectivity over Mn-based catalysts. Therefore, it is necessary to carry out this research in the near future.

(6) Most studies focus on powder catalysts. From a commercial perspective, monolithic catalysts should be given more consideration.

Acknowledgments: This work was sponsored by the National Natural Science Fund Committee-Baosteel Group Corporation Steel Joint Research Fund, China (U1460105), the National Science Foundation of China (51521065), and the Natural Science Foundation of Shaanxi Province, China (2015JM2055).

Conflicts of Interest: There are no conflict of interest.

\section{References}

1. Kapteijn, F.; Rodriguez-Mirasol, J.; Moulijn, J.A. Heterogeneous catalytic decomposition of nitrous oxide. Appl. Catal. B Environ. 1996, 9, 25-64. [CrossRef]

2. Pârvulescu, V.I.; Grange, P.; Delmon, B. Catalytic removal of NO. Catal. Today 1998, 46, 233-316. [CrossRef] 
3. Forzatti, P. Present status and perspectives in de-NO $\mathrm{NO}_{x} \mathrm{SCR}$ catalysis. Appl. Catal. A Gen. 2001, 222, 221-236. [CrossRef]

4. Kapteijn, F.; Singoredjo, L.; Andreini, A.; Moulijn, J.A. Activity and selectivity of pure manganese oxides in the selective catalytic reduction of nitric oxide with ammonia. Appl. Catal. B Environ. 1994, 3, 173-189. [CrossRef]

5. Boningari, T.; Smirniotis, P.G. Impact of nitrogen oxides on the environment and human health: Mn-based materials for the $\mathrm{NO}_{x}$ abatement. Curr. Opin. Chem. Eng. 2016, 13, 133-141. [CrossRef]

6. Busca, G.; Lietti, L.; Ramis, G.; Berti, F. Chemical and mechanistic aspects of the selective catalytic reduction of $\mathrm{NO}_{x}$ by ammonia over oxide catalysts: A review. Appl. Catal. B Environ. 1998, 18, 1-36. [CrossRef]

7. Boningari, T.; Koirala, R.; Smirniotis, P.G. Low-temperature selective catalytic reduction of $\mathrm{NO}_{\text {with }} \mathrm{NH}_{3}$ over $\mathrm{V} / \mathrm{ZrO}_{2}$ prepared by flame-assisted spray pyrolysis: Structural and catalytic properties. Appl. Catal. B Environ. 2012, 127, 255-264. [CrossRef]

8. Roy, S.; Hegde, M.S.; Madras, G. Catalysis for $\mathrm{NO}_{x}$ abatement. Appl. Energy 2009, 86, 2283-2297. [CrossRef]

9. Wu, Z.; Jin, R.; Wang, H.; Liu, Y. Effect of ceria doping on $\mathrm{SO}_{2}$ resistance of $\mathrm{Mn} / \mathrm{TiO}_{2}$ for selective catalytic reduction of $\mathrm{NO}$ with $\mathrm{NH}_{3}$ at low temperature. Catal. Commun. 2009, 10, 935-939. [CrossRef]

10. Chen, Z.; Yang, Q.; Li, H.; Li, X.; Wang, L.; Chi Tsang, S. Cr-MnO $x$ mixed-oxide catalysts for selective catalytic reduction of $\mathrm{NO}_{x}$ with $\mathrm{NH}_{3}$ at low temperature. J. Catal. 2010, 276, 56-65. [CrossRef]

11. Wu, Z.; Jiang, B.; Liu, Y.; Wang, H.; Jin, R. DRIFT study of Manganese/Titania-based catalysts for low-temperature selective catalytic reduction of $\mathrm{NO}$ with $\mathrm{NH}_{3}$. Environ. Sci. Technol. 2007, 41, 5812-5817. [CrossRef] [PubMed]

12. Kang, M.; Park, E.D.; Kim, J.M.; Yie, J.E. Manganese oxide catalysts for $\mathrm{NO}_{x}$ reduction with $\mathrm{NH}_{3}$ at low temperatures. Appl. Catal. A Gen. 2007, 327, 261-269. [CrossRef]

13. Tang, X.; Hao, J.; Xu, W.; Li, J. Low temperature selective catalytic reduction of $\mathrm{NO}_{x}$ with $\mathrm{NH}_{3}$ over amorphous $\mathrm{MnO}_{x}$ catalysts prepared by three methods. Catal. Commun. 2007, 8, 329-334. [CrossRef]

14. Tian, W.; Yang, H.; Fan, X.; Zhang, X. Catalytic reduction of $\mathrm{NO}_{x}$ with $\mathrm{NH}_{3}$ over different-shaped $\mathrm{MnO}_{2}$ at low temperature. J. Hazard. Mater. 2011, 188, 105-109. [CrossRef] [PubMed]

15. Fan, Z.; Shi, J.W.; Gao, C.; Gao, G.; Wang, B.; Niu, C. Rationally designed porous $\mathrm{MnO}_{x}-\mathrm{FeO}_{x}$ nanoneedles for low-temperature selective catalytic reduction of $\mathrm{NO}_{x}$ by $\mathrm{NH}_{3}$. ACS Appl. Mater. Interfaces 2017, 9, 16117-16127. [CrossRef] [PubMed]

16. Gao, G.; Shi, J.-W.; Fan, Z.; Gao, C.; Niu, C. $\mathrm{MnM}_{2} \mathrm{O}_{4}$ microspheres (M = Co, Cu, Ni) for selective catalytic reduction of $\mathrm{NO}$ with $\mathrm{NH}_{3}$ : Comparative study on catalytic activity and reaction mechanism via in-situ diffuse reflectance infrared Fourier transform spectroscopy. Chem. Eng. J. 2017, 325, 91-100. [CrossRef]

17. Gao, G.; Shi, J.-W.; Liu, C.; Gao, C.; Fan, Z.; Niu, C. Mn/CeO 2 catalysts for SCR of $\mathrm{NO}_{x}$ with $\mathrm{NH}_{3}$ : Comparative study on the effect of supports on low-temperature catalytic activity. Appl. Surf. Sci. 2017, 411, 338-346. [CrossRef]

18. Gao, C.; Shi, J.-W.; Fan, Z.; Yu, Y.; Chen, J.; Li, Z.; Niu, C. Eu-Mn-Ti mixed oxides for the SCR of NO $\mathrm{NO}_{x}$ with $\mathrm{NH}_{3}$ : The effects of Eu-modification on catalytic performance and mechanism. Fuel Process. Technol. 2017, 167, 322-333. [CrossRef]

19. Xie, C.; Yang, S.; Shi, J.; Li, B.; Gao, C.; Niu, C. $\mathrm{MnO}_{x}-\mathrm{TiO}_{2}$ and $\mathrm{Sn}$ doped $\mathrm{MnO}_{x}-\mathrm{TiO}_{2}$ selective reduction catalysts prepared using MWCNTs as the pore template. Chem. Eng. J. 2017, 327, 1-8. [CrossRef]

20. Shi, J.-W.; Gao, C.; Liu, C.; Fan, Z.; Gao, G.; Niu, C. Porous $\mathrm{MnO}_{x}$ for low-temperature $\mathrm{NH}_{3}-\mathrm{SCR}$ of $\mathrm{NO}_{x}$ : The intrinsic relationship between surface physicochemical property and catalytic activity. J. Nanopart. Res. 2017, 19, 194-205. [CrossRef]

21. Liu, C.; Gao, G.; Shi, J.-W.; He, C.; Li, G.; Bai, N.; Niu, C. $\mathrm{MnO}_{x}-\mathrm{CeO}_{2}$ shell-in-shell microspheres for $\mathrm{NH}_{3}-\mathrm{SCR}$ de- $\mathrm{NO}_{x}$ at low temperature. Catal. Commun. 2016, 86, 36-40. [CrossRef]

22. Loiland, J.A.; Lobo, R.F. Low temperature catalytic NO oxidation over microporous materials. J. Catal. 2014, 311, 412-423. [CrossRef]

23. Kang, M.; Yeon, T.H.; Park, E.D.; Yie, J.E.; Kim, J.M. Novel $\mathrm{MnO}_{x}$ catalysts for $\mathrm{NO}$ reduction at low temperature with ammonia. Catal. Lett. 2006, 106, 77-80. [CrossRef]

24. Qi, G.; Yang, R.T. A superior catalyst for low-temperature $\mathrm{NO}$ reduction with $\mathrm{NH}_{3}$. Chem. Commun. 2003, 848-849. [CrossRef]

25. Liu, Z.; Yi, Y.; Zhang, S.; Zhu, T.; Zhu, J.; Wang, J. Selective catalytic reduction of $\mathrm{NO}_{x}$ with $\mathrm{NH}_{3}$ over Mn-Ce mixed oxide catalyst at low temperatures. Catal. Today 2013, 216, 76-81. [CrossRef] 
26. Yao, X.; Kong, T.; Chen, L.; Ding, S.; Yang, F.; Dong, L. Enhanced low-temperature $\mathrm{NH}_{3}-\mathrm{SCR}$ performance of $\mathrm{MnO}_{x} / \mathrm{CeO}_{2}$ catalysts by optimal solvent effect. Appl. Surf. Sci. 2017, 420, 407-415. [CrossRef]

27. Long, R.Q.; Yang, R.T.; Chang, R. Low temperature selective catalytic reduction (SCR) of NO with $\mathrm{NH}_{3}$ over Fe-Mn based catalysts. Chem. Commun. 2002, 452-453. [CrossRef]

28. Chen, Z.; Wang, F.; Li, H.; Yang, Q.; Wang, L.; Li, X. Low-temperature selective catalytic reduction of $\mathrm{NO}_{x}$ with $\mathrm{NH}_{3}$ over $\mathrm{Fe}-\mathrm{Mn}$ mixed-oxide catalysts containing $\mathrm{Fe}_{3} \mathrm{Mn}_{3} \mathrm{O}_{8}$ Phase. Ind. Eng. Chem. Res. 2012, 51, 202-212. [CrossRef]

29. Zhang, L.; Shi, L.; Huang, L.; Zhang, J.; Gao, R.; Zhang, D. Rational design of high-performance deNO ${ }_{x}$ catalysts based on $\mathrm{Mn}_{x} \mathrm{Co}_{3-x} \mathrm{O}_{4}$ nanocages derived from metal-organic frameworks. ACS Catal. 2014, 4, 1753-1763. [CrossRef]

30. Qiu, M.; Zhan, S.; Yu, H.; Zhu, D. Low-temperature selective catalytic reduction of NO with $\mathrm{NH}_{3}$ over ordered mesoporous $\mathrm{Mn}_{x} \mathrm{Co}_{3-x} \mathrm{O}_{4}$ catalyst. Catal. Commun. 2015, 62, 107-111. [CrossRef]

31. Qiu, M.; Zhan, S.; Yu, H.; Zhu, D.; Wang, S. Facile preparation of ordered mesoporous $\mathrm{MnCo}_{2} \mathrm{O}_{4}$ for low-temperature selective catalytic reduction of $\mathrm{NO}$ with $\mathrm{NH}_{3}$. Nanoscale 2015, 7, 2568-2577. [CrossRef] [PubMed]

32. Kang, M.; Park, E.D.; Kim, J.M.; Yie, J.E. Cu-Mn mixed oxides for low temperature NO reduction with $\mathrm{NH}_{3}$. Catal. Today 2006, 111, 236-241. [CrossRef]

33. Meng, D.; Zhan, W.; Guo, Y.; Guo, Y.; Wang, L.; Lu, G. A highly effective catalyst of Sm-MnO $\mathrm{S}_{x}$ for the $\mathrm{NH}_{3}$-SCR of $\mathrm{NO}_{x}$ at low temperature: Promotional role of Sm and its catalytic performance. ACS Catal. 2015, 5, 5973-5983. [CrossRef]

34. Sun, P.; Guo, R.-T.; Liu, S.-M.; Wang, S.-X.; Pan, W.-G.; Li, M.-Y. The enhanced performance of $\mathrm{MnO}_{x}$ catalyst for $\mathrm{NH}_{3}-\mathrm{SCR}$ reaction by the modification with Eu. Appl. Catal. A Gen. 2017, 531, 129-138. [CrossRef]

35. Qi, G.; Yang, R.T.; Chang, R. $\mathrm{MnO}_{x}-\mathrm{CeO}_{2}$ mixed oxides prepared by co-precipitation for selective catalytic reduction of $\mathrm{NO}$ with $\mathrm{NH}_{3}$ at low temperatures. Appl. Catal. B Environ. 2004, 51, 93-106. [CrossRef]

36. France, L.J.; Yang, Q.; Li, W.; Chen, Z.; Guang, J.; Guo, D.; Wang, L.; Li, X. Ceria modified FeMnO ${ }_{x}$-Enhanced performance and sulphur resistance for low-temperature SCR of $\mathrm{NO}_{x}$. Appl. Catal. B Environ. 2017, 206, 203-215. [CrossRef]

37. Chang, H.; Li, J.; Chen, X.; Ma, L.; Yang, S.; Schwank, J.W.; Hao, J. Effect of Sn on $\mathrm{MnO}_{x}-\mathrm{CeO}_{2}$ catalyst for $\mathrm{SCR}$ of $\mathrm{NO}_{x}$ by ammonia: Enhancement of activity and remarkable resistance to $\mathrm{SO}_{2}$. Catal. Commun. 2012, 27, 54-57. [CrossRef]

38. Chang, H.; Chen, X.; Li, J.; Ma, L.; Wang, C.; Liu, C.; Schwank, J.W.; Hao, J. Improvement of activity and $\mathrm{SO}_{2}$ tolerance of Sn-modified $\mathrm{MnO}_{x}-\mathrm{CeO}_{2}$ catalysts for $\mathrm{NH}_{3}-\mathrm{SCR}$ at low temperatures. Environ. Sci. Technol. 2013, 47, 5294-5301. [CrossRef] [PubMed]

39. Gao, F.; Tang, X.; Yi, H.; Li, J.; Zhao, S.; Wang, J.; Chu, C.; Li, C. Promotional mechanisms of activity and $\mathrm{SO}_{2}$ tolerance of $\mathrm{Co}$ - or Ni-doped $\mathrm{MnO}_{x}-\mathrm{CeO}_{2}$ catalysts for SCR of $\mathrm{NO}_{x}$ with $\mathrm{NH}_{3}$ at low temperature. Chem. Eng. J. 2017, 317, 20-31. [CrossRef]

40. Liu, Z.; Liu, Y.; Li, Y.; Su, H.; Ma, L. $\mathrm{WO}_{3}$ promoted Mn-Zr mixed oxide catalyst for the selective catalytic reduction of $\mathrm{NO}_{x}$ with $\mathrm{NH}_{3}$. Chem. Eng. J. 2016, 283, 1044-1050. [CrossRef]

41. Qi, G.; Yang, R.T. Low-temperature selective catalytic reduction of $\mathrm{NO}$ with $\mathrm{NH}_{3}$ over iron and manganese oxides supported on titania. Appl. Catal. B Environ. 2003, 44, 217-225. [CrossRef]

42. Yang, S.; Qi, F.; Xiong, S.; Dang, H.; Liao, Y.; Wong, P.K.; Li, J. MnO $x$ supported on Fe-Ti spinel: A novel Mn based low temperature SCR catalyst with a high $\mathrm{N}_{2}$ selectivity. Appl. Catal. B Environ. 2016, 181, 570-580. [CrossRef]

43. Shen, B.; Liu, T.; Zhao, N.; Yang, X.; Deng, L. Iron-doped Mn-Ce/ $\mathrm{TiO}_{2}$ catalyst for low temperature selective catalytic reduction of $\mathrm{NO}$ with $\mathrm{NH}_{3}$. J. Environ. Sci. 2010, 22, 1447-1454. [CrossRef]

44. Shen, B.; Ma, H.; Yao, Y. Mn-CeO $/$ Ti-PILCs for selective catalytic reduction of $\mathrm{NO}$ with $\mathrm{NH}_{3}$ at low temperature. J. Environ. Sci. 2012, 24, 499-506. [CrossRef]

45. Lee, S.M.; Park, K.H.; Hong, S.C. $\mathrm{MnO}_{x} / \mathrm{CeO}_{2}-\mathrm{TiO}_{2}$ mixed oxide catalysts for the selective catalytic reduction of $\mathrm{NO}$ with $\mathrm{NH}_{3}$ at low temperature. Chem. Eng. J. 2012, 195-196, 323-331. [CrossRef]

46. Liu, Z.; Zhu, J.; Li, J.; Ma, L.; Woo, S.I. Novel Mn-Ce-Ti mixed-oxide catalyst for the selective catalytic reduction of $\mathrm{NO}_{x}$ with $\mathrm{NH}_{3}$. ACS Appl. Mater. Interfaces 2014, 6, 14500-14508. [CrossRef] [PubMed] 
47. Chen, L.; Li, R.; Li, Z.; Yuan, F.; Niu, X.; Zhu, Y. Effect of Ni doping in $\mathrm{Ni}_{x} \mathrm{Mn}_{1-x} \mathrm{Ti}_{10}(x=0.1-0.5)$ on activity and $\mathrm{SO}_{2}$ resistance for $\mathrm{NH}_{3}-\mathrm{SCR}$ of $\mathrm{NO}$ studied with in situ DRIFTS. Catal. Sci. Technol. 2017, 7, 3243-3257. [CrossRef]

48. Zhang, D.; Zhang, L.; Shi, L.; Fang, C.; Li, H.; Gao, R.; Huang, L.; Zhang, J. In situ supported $\mathrm{MnO}_{x}-\mathrm{CeO}_{x}$ on carbon nanotubes for the low-temperature selective catalytic reduction of $\mathrm{NO}$ with $\mathrm{NH}_{3}$. Nanoscale 2013, 5 , 1127-1136. [CrossRef] [PubMed]

49. Cai, S.; Hu, H.; Li, H.; Shi, L.; Zhang, D. Design of multi-shell $\mathrm{Fe}_{2} \mathrm{O}_{3} @ \mathrm{MnO}_{\mathbf{x}} @ \mathrm{CNTs}$ for the selective catalytic reduction of $\mathrm{NO}$ with $\mathrm{NH}_{3}$ : Improvement of catalytic activity and $\mathrm{SO}_{2}$ tolerance. Nanoscale 2016, 8, 3588-3598. [CrossRef] [PubMed]

50. Lu, X.; Song, C.; Chang, C.-C.; Teng, Y.; Tong, Z.; Tang, X. Manganese oxides supported on $\mathrm{TiO}_{2}-$ graphene nanocomposite catalysts for selective catalytic reduction of $\mathrm{NO}_{x}$ with $\mathrm{NH}_{3}$ at low temperature. Ind. Eng. Chem. Res. 2014, 53, 11601-11610. [CrossRef]

51. Lu, X.; Song, C.; Jia, S.; Tong, Z.; Tang, X.; Teng, Y. Low-temperature selective catalytic reduction of $\mathrm{NO}_{x}$ with $\mathrm{NH}_{3}$ over cerium and manganese oxides supported on $\mathrm{TiO}_{2}$-graphene. Chem. Eng. J. 2015, 260, 776-784. [CrossRef]

52. Shen, B.; Wang, Y.; Wang, F.; Liu, T. The effect of Ce-Zr on $\mathrm{NH}_{3}-\mathrm{SCR}$ activity over $\mathrm{MnO}_{x}(0.6) / \mathrm{Ce}_{0.5} \mathrm{Zr}_{0.5} \mathrm{O}_{2}$ at low temperature. Chem. Eng. J. 2014, 236, 171-180. [CrossRef]

53. Zhang, T.; Qiu, F.; Chang, H.; Peng, Y.; Li, J. Novel W-modified $\mathrm{SnMnCeO}_{x}$ catalyst for the selective catalytic reduction of $\mathrm{NO}_{x}$ with $\mathrm{NH}_{3}$. Catal. Commun. 2017, 100, 117-120. [CrossRef]

54. Gao, X.; Li, L.; Song, L.; Lu, T.; Zhao, J.; Liu, Z. Highly dispersed $\mathrm{MnO}_{x}$ nanoparticles supported on three-dimensionally ordered macroporous carbon: A novel nanocomposite for catalytic reduction of $\mathrm{NO}_{x}$ with $\mathrm{NH}_{3}$ at low temperature. RSC Adv. 2015, 5, 29577-29588. [CrossRef]

55. Wang, X.; Li, X.; Zhao, Q.; Sun, W.; Tade, M.; Liu, S. Improved activity of W-modified $\mathrm{MnO}_{x}-\mathrm{TiO}_{2}$ catalysts for the selective catalytic reduction of $\mathrm{NO}$ with $\mathrm{NH}_{3}$. Chem. Eng. J. 2016, 288, 216-222. [CrossRef]

56. Apostolescu, N.; Geiger, B.; Hizbullah, K.; Jan, M.; Kureti, S.; Reichert, D.; Schott, F.; Weisweiler, W. Selective catalytic reduction of nitrogen oxides by ammonia on iron oxide catalysts. Appl. Catal. B Environ. 2006, 62, 104-114. [CrossRef]

57. Lee, T.; Bai, H. Low temperature selective catalytic reduction of $\mathrm{NO}_{x}$ with $\mathrm{NH}_{3}$ over Mn-based catalyst: A review. AIMS Environ. Sci. 2016, 3, 261-289. [CrossRef]

58. Yao, Y.; Zhang, S.-L.; Zhong, Q.; Liu, X.-X. Low-temperature selective catalytic reduction of NO over manganese supported on $\mathrm{TiO}_{2}$ nanotubes. J. Fuel Chem. Technol. 2011, 39, 694-701. [CrossRef]

59. Li, J.; Chang, H.; Ma, L.; Hao, J.; Yang, R.T. Low-temperature selective catalytic reduction of $\mathrm{NO}_{x}$ with $\mathrm{NH}_{3}$ over metal oxide and zeolite catalysts-A review. Catal. Today 2011, 175, 147-156. [CrossRef]

60. Liu, F.; He, H.; Zhang, C.; Shan, W.; Shi, X. Mechanism of the selective catalytic reduction of $\mathrm{NO}_{x}$ with $\mathrm{NH}_{3}$ over environmental-friendly iron titanate catalyst. Catal. Today 2011, 175, 18-25. [CrossRef]

61. Qu, L.; Li, C.; Zeng, G.; Zhang, M.; Fu, M.; Ma, J.; Zhan, F.; Luo, D. Support modification for improving the performance of $\mathrm{MnO}_{x}-\mathrm{CeO}_{y} / \gamma-\mathrm{Al}_{2} \mathrm{O}_{3}$ in selective catalytic reduction of $\mathrm{NO}$ by $\mathrm{NH}_{3}$. Chem. Eng. J. 2014, 242, 76-85. [CrossRef]

62. Schill, L.; Putluru, S.S.R.; Jensen, A.D.; Fehrmann, R. $\mathrm{MnFe} / \mathrm{Al}_{2} \mathrm{O}_{3}$ catalyst synthesized by deposition precipitation for low-temperature selective catalytic reduction of $\mathrm{NO}$ with $\mathrm{NH}_{3}$. Catal. Lett. 2015, 145, 1724-1732. [CrossRef]

63. Gao, R.; Zhang, D.; Liu, X.; Shi, L.; Maitarad, P.; Li, H.; Zhang, J.; Cao, W. Enhanced catalytic performance of $\mathrm{V}_{2} \mathrm{O}_{5}-\mathrm{WO}_{3} / \mathrm{Fe}_{2} \mathrm{O}_{3} / \mathrm{TiO}_{2}$ microspheres for selective catalytic reduction of $\mathrm{NO}$ by $\mathrm{NH}_{3}$. Catal. Sci. Technol. 2013, 3, 191-199. [CrossRef]

64. Zhang, L.; Li, L.; Cao, Y.; Yao, X.; Ge, C.; Gao, F.; Deng, Y.; Tang, C.; Dong, L. Getting insight into the influence of $\mathrm{SO}_{2}$ on $\mathrm{TiO}_{2} / \mathrm{CeO}_{2}$ for the selective catalytic reduction of $\mathrm{NO}$ by $\mathrm{NH}_{3}$. Appl. Catal. B Environ. 2015, 165, 589-598. [CrossRef]

65. Xu, W.; He, H.; Yu, Y. Deactivation of a $\mathrm{Ce} / \mathrm{TiO}_{2}$ catalyst by $\mathrm{SO}_{2}$ in the selective catalytic reduction of $\mathrm{NO}$ by $\mathrm{NH}_{3}$. J. Phys. Chem. C 2009, 113, 4426-4432. [CrossRef]

66. Jiang, B.Q.; Wu, Z.B.; Liu, Y.; Lee, S.C.; Ho, W.K. DRIFT study of the $\mathrm{SO}_{2}$ effect on low-temperature SCR reaction over $\mathrm{Fe}-\mathrm{Mn} / \mathrm{TiO}_{2}$. J. Phys. Chem. C 2010, 114, 4961-4965. [CrossRef] 
67. Long, R.Q.; Yang, R.T. Superior Fe-ZSM-5 catalyst for selective catalytic reduction of nitric oxide by ammonia. J. Am. Chem. Soc. 1999, 121, 5595-5596. [CrossRef]

68. Xiong, S.; Liao, Y.; Xiao, X.; Dang, H.; Yang, S. The mechanism of the effect of $\mathrm{H}_{2} \mathrm{O}$ on the low temperature selective catalytic reduction of $\mathrm{NO}$ with $\mathrm{NH}_{3}$ over Mn-Fe spinel. Catal. Sci. Technol. 2015, 5, 2132-2140. [CrossRef]

69. Xiong, S.; Liao, Y.; Xiao, X.; Dang, H.; Yang, S. Novel Effect of $\mathrm{H}_{2} \mathrm{O}$ on the low temperature selective catalytic reduction of $\mathrm{NO}$ with $\mathrm{NH}_{3}$ over $\mathrm{MnO}_{x}-\mathrm{CeO}_{2}$ : Mechanism and kinetic study. J. Phys. Chem. C 2015, 119, 4180-4187. [CrossRef]

70. Marban, G. Mechanism of low-temperature selective catalytic reduction of $\mathrm{NO}$ with $\mathrm{NH}_{3}$ over carbon-supported $\mathrm{Mn}_{3} \mathrm{O}_{4}$. Role of surface $\mathrm{NH}_{3}$ species: SCR mechanism. J. Catal. 2004, 226, 138-155. [CrossRef]

71. Tang, X.; Li, J.; Sun, L.; Hao, J. Origination of $\mathrm{N}_{2} \mathrm{O}$ from $\mathrm{NO}$ reduction by $\mathrm{NH}_{3}$ over $\beta-\mathrm{MnO}_{2}$ and $\alpha-\mathrm{Mn}_{2} \mathrm{O}_{3}$. Appl. Catal. B Environ. 2010, 99, 156-162. [CrossRef]

72. Wang, C.; Sun, L.; Cao, Q.; Hu, B.; Huang, Z.; Tang, X. Surface structure sensitivity of manganese oxides for low-temperature selective catalytic reduction of $\mathrm{NO}$ with $\mathrm{NH}_{3}$. Appl. Catal. B Environ. 2011, 101, 598-605. [CrossRef]

73. Liu, C.; Shi, J.-W.; Gao, C.; Niu, C. Manganese oxide-based catalysts for low-temperature selective catalytic reduction of $\mathrm{NO}_{x}$ with $\mathrm{NH}_{3}$ : A review. Appl. Catal. A Gen. 2016, 522, 54-69. [CrossRef]

74. Chen, L.; Si, Z.; Wu, X.; Weng, D.; Ran, R.; Yu, J. Rare earth containing catalysts for selective catalytic reduction of $\mathrm{NO}_{x}$ with ammonia: A review. J. Rare Earths 2014, 32, 907-917. [CrossRef]

75. Smirniotis, P.G.; Peña, D.A.; Uphade, B.S. Low-temperature selective catalytic reduction (SCR) of NO with $\mathrm{NH}_{3}$ by using $\mathrm{Mn}, \mathrm{Cr}$, and $\mathrm{Cu}$ oxides supported on hombikat $\mathrm{TiO}_{2}$. Angew. Chem. Int. Ed. 2001, 40, 2479-2482. [CrossRef]

76. Yang, S.; Wang, C.; Li, J.; Yan, N.; Ma, L.; Chang, H. Low temperature selective catalytic reduction of NO with $\mathrm{NH}_{3}$ over Mn-Fe spinel: Performance, mechanism and kinetic study. Appl. Catal. B Environ. 2011, 110, 71-80. [CrossRef]

77. Chen, L.; Niu, X.; Li, Z.; Dong, Y.; Zhang, Z.; Yuan, F.; Zhu, Y. Promoting catalytic performances of Ni-Mn spinel for $\mathrm{NH}_{3}-\mathrm{SCR}$ by treatment with $\mathrm{SO}_{2}$ and $\mathrm{H}_{2} \mathrm{O}$. Catal. Commun. 2016, 85, 48-51. [CrossRef]

78. Yang, S.; Guo, Y.; Chang, H.; Ma, L.; Peng, Y.; Qu, Z.; Yan, N.; Wang, C.; Li, J. Novel effect of SO 2 on the SCR reaction over $\mathrm{CeO}_{2}$ : Mechanism and significance. Appl. Catal. B Environ. 2013, 136-137, 19-28. [CrossRef]

79. Liu, Y.; Cen, W.; Wu, Z.; Weng, X.; Wang, H. $\mathrm{SO}_{2}$ poisoning structures and the effects on pure and Mn doped $\mathrm{CeO}_{2}$ : A first principles investigation. J. Phys. Chem. C 2012, 116, 22930-22937. [CrossRef]

80. Yu, J.; Guo, F.; Wang, Y.; Zhu, J.; Liu, Y.; Su, F.; Gao, S.; Xu, G. Sulfur poisoning resistant mesoporousMn-based catalyst for low-temperature SCR of $\mathrm{NO}$ with $\mathrm{NH}_{3}$. Appl. Catal. B Environ. 2010, 95, 160-168. [CrossRef]

81. Wang, Y.; Li, X.; Zhan, L.; Li, C.; Qiao, W.; Ling, L. Effect of $\mathrm{SO}_{2}$ on activated carbon honeycomb supported $\mathrm{CeO}_{2}-\mathrm{MnO}_{x}$ catalyst for $\mathrm{NO}$ removal at low temperature. Ind. Eng. Chem. Res. 2015, 54, 2274-2278. [CrossRef]

82. Wei, Y.; Sun, Y.; Su, W.; Liu, J. $\mathrm{MnO}_{2}$ doped $\mathrm{CeO}_{2}$ with tailored 3-D channels exhibits excellent performance for $\mathrm{NH}_{3}-\mathrm{SCR}$ of NO. RSC Adv. 2015, 5, 26231-26235. [CrossRef]

83. Park, E.; Kim, M.; Jung, H.; Chin, S.; Jurng, J. Effect of sulfur on Mn/Ti catalysts prepared using chemical vapor condensation (CVC) for low-temperature NO reduction. ACS Catal. 2013, 3, 1518-1525. [CrossRef]

84. Lu, P.; Li, C.; Zeng, G.; He, L.; Peng, D.; Cui, H.; Li, S.; Zhai, Y. Low temperature selective catalytic reduction of NO by activated carbon fiber loading lanthanum oxide and ceria. Appl. Catal. B Environ. 2010, 96, 157-161. [CrossRef]

85. Sui, M.; Xing, S.; Sheng, L.; Huang, S.; Guo, H. Heterogeneous catalytic ozonation of ciprofloxacin in water with carbon nanotube supported manganese oxides as catalyst. J. Hazard. Mater. 2012, 227-228, 227-236. [CrossRef] [PubMed]

86. Wang, L.; Huang, B.; Su, Y.; Zhou, G.; Wang, K.; Luo, H.; Ye, D. Manganese oxides supported on multi-walled carbon nanotubes for selective catalytic reduction of $\mathrm{NO}$ with $\mathrm{NH}_{3}$ : Catalytic activity and characterization. Chem. Eng. J. 2012, 192, 232-241. [CrossRef]

87. Yao, X.; Kong, T.; Yu, S.; Li, L.; Yang, F.; Dong, L. Influence of different supports on the physicochemical properties and denitration performance of the supported Mn-based catalysts for $\mathrm{NH}_{3}-\mathrm{SCR}$ at low temperature. Appl. Surf. Sci. 2017, 402, 208-217. [CrossRef] 
88. Huang, J.; Tong, Z.; Huang, Y.; Zhang, J. Selective catalytic reduction of $\mathrm{NO}$ with $\mathrm{NH}_{3}$ at low temperatures over iron and manganese oxides supported on mesoporous silica. Appl. Catal. B Environ. 2008, 78, 309-314. [CrossRef]

89. Kwon, D.W.; Nam, K.B.; Hong, S.C. The role of ceria on the activity and $\mathrm{SO}_{2}$ resistance of catalysts for the selective catalytic reduction of $\mathrm{NO}_{x}$ by $\mathrm{NH}_{3}$. Appl. Catal. B Environ. 2015, 166-167, 37-44. [CrossRef]

90. Xiao, X.; Xiong, S.; Shi, Y.; Shan, W.; Yang, S. Effect of $\mathrm{H}_{2} \mathrm{O}$ and $\mathrm{SO}_{2}$ on the selective catalytic reduction of $\mathrm{NO}$ with $\mathrm{NH}_{3}$ over $\mathrm{Ce} / \mathrm{TiO}_{2}$ catalyst: Mechanism and kinetic Study. J. Phys. Chem. C 2016, 120, 1066-1076. [CrossRef]

91. Tang, X.; Hao, J.; Yi, H.; Li, J. Low-temperature SCR of $\mathrm{NO}$ with $\mathrm{NH}_{3}$ over AC/C supported manganese-based monolithic catalysts. Catal. Today 2007, 126, 406-411. [CrossRef]

92. Kwon, D.W.; Nam, K.B.; Hong, S.C. Influence of tungsten on the activity of a Mn/Ce/W/Ti catalyst for the selective catalytic reduction of $\mathrm{NO}_{\text {with }} \mathrm{NH}_{3}$ at low temperatures. Appl. Catal. A Gen. 2015, 497, 160-166. [CrossRef]

93. Chen, Q.-L.; Guo, R.-T.; Wang, Q.-S.; Pan, W.-G.; Wang, W.-H.; Yang, N.-Z.; Lu, C.-Z.; Wang, S.-X. The catalytic performance of $\mathrm{Mn} / \mathrm{TiWO}_{x}$ catalyst for selective catalytic reduction of $\mathrm{NO}_{x}$ with $\mathrm{NH}_{3}$. Fuel 2016, 181, 852-858. [CrossRef]

94. Qi, G.; Yang, R.T. Characterization and FTIR studies of $\mathrm{MnO}_{x}-\mathrm{CeO}_{2}$ catalyst for low-temperature selective catalytic reduction of $\mathrm{NO}$ with $\mathrm{NH}_{3}$. J. Phys. Chem. B 2004, 108, 15738-15747. [CrossRef]

95. Guo, F.; Yu, J.; Chu, M.; Xu, G. Interaction between support and $\mathrm{V}_{2} \mathrm{O}_{5}$ in the selective catalytic reduction of $\mathrm{NO}$ by $\mathrm{NH}_{3}$. Catal. Sci. Technol. 2014, 4, 2147-2155. [CrossRef]

96. Jin, R.; Liu, Y.; Wu, Z.; Wang, H.; Gu, T. Low-temperature selective catalytic reduction of $\mathrm{NO}_{\text {with }} \mathrm{NH}_{3}$ over MnCe oxides supported on $\mathrm{TiO}_{2}$ and $\mathrm{Al}_{2} \mathrm{O}_{3}$ : A comparative study. Chemosphere 2010, 78, 1160-1166. [CrossRef] [PubMed]

97. Pappas, D.K.; Boningari, T.; Boolchand, P.; Smirniotis, P.G. Novel manganese oxide confined interweaved titania nanotubes for the low-temperature Selective Catalytic Reduction (SCR) of $\mathrm{NO}_{x}$ by $\mathrm{NH}_{3}$. J. Catal. 2016, 334, 1-13. [CrossRef]

98. Wang, X.; Zheng, Y.; Xu, Z.; Liu, X.; Zhang, Y. Low-temperature selective catalytic reduction of NO over $\mathrm{MnO}_{x} / \mathrm{CNTs}$ catalysts. Catal. Commun. 2014, 50, 34-37. [CrossRef]

99. Zhang, Y.; Zheng, Y.; Wang, X.; Lu, X. Preparation of Mn-FeO $x / C N T s$ catalysts by redox co-precipitation and application in low-temperature $\mathrm{NO}$ reduction with $\mathrm{NH}_{3}$. Catal. Commun. 2015, 62, 57-61. [CrossRef]

100. Zhao, B.; Ran, R.; Guo, X.; Cao, L.; Xu, T.; Chen, Z.; Wu, X.; Si, Z.; Weng, D. Nb-modified Mn/Ce/Ti catalyst for the selective catalytic reduction of $\mathrm{NO}$ with $\mathrm{NH}_{3}$ at low temperature. Appl. Catal. A Gen. 2017, 545, 64-71. [CrossRef]

101. Shen, Q.; Zhang, L.; Sun, N.; Wang, H.; Zhong, L.; He, C.; Wei, W.; Sun, Y. Hollow $\mathrm{MnO}_{x}-\mathrm{CeO}_{2}$ mixed oxides as highly efficient catalysts in NO oxidation. Chem. Eng. J. 2017, 322, 46-55. [CrossRef]

102. Li, Y.; Wan, Y.; Li, Y.; Zhan, S.; Guan, Q.; Tian, Y. Low-temperature selective catalytic reduction of NO with $\mathrm{NH}_{3}$ over $\mathrm{Mn}_{2} \mathrm{O}_{3}$-doped $\mathrm{Fe}_{2} \mathrm{O}_{3}$ hexagonal microsheets. ACS Appl. Mater. Interfaces 2016, 8, 5224-5233. [CrossRef] [PubMed]

103. Tomašić, V. Application of the monoliths in $\mathrm{DeNO}_{x}$ catalysis. Catal. Today 2007, 119, 106-113. [CrossRef]

104. Heck, R.M.; Gulati, S.; Farrauto, R.J. The application of monoliths for gas phase catalytic reactions. Chem. Eng. J. 2001, 82, 149-156. [CrossRef]

105. Shan, W.; Song, H. Catalysts for the selective catalytic reduction of $\mathrm{NO}_{x}$ with $\mathrm{NH}_{3}$ at low temperature. Catal. Sci. Technol. 2015, 5, 4280-4288. [CrossRef]

106. Ouzzine, M.; Cifredo, G.A.; Gatica, J.M.; Harti, S.; Chafik, T.; Vidal, H. Original carbon-based honeycomb monoliths as support of $\mathrm{Cu}$ or Mn catalysts for low-temperature SCR of NO: Effects of preparation variables. Appl. Catal. A Gen. 2008, 342, 150-158. [CrossRef]

107. Li, H.; Zhang, D.; Maitarad, P.; Shi, L.; Gao, R.; Zhang, J.; Cao, W. In situ synthesis of 3D flower-like NiMnFe mixed oxides as monolith catalysts for selective catalytic reduction of $\mathrm{NO}$ with $\mathrm{NH}_{3}$. Chem. Commun. 2012, 48, 10645-10647. [CrossRef] [PubMed] 
108. Shu, Y.; Aikebaier, T.; Quan, X.; Chen, S.; Yu, H. Selective catalytic reaction of $\mathrm{NO}_{x}$ with $\mathrm{NH}_{3}$ over $\mathrm{Ce}-\mathrm{Fe} / \mathrm{TiO}_{2}$-loaded wire-mesh honeycomb: Resistance to $\mathrm{SO}_{2}$ poisoning. Appl. Catal. B Environ. 2014, 150-151, 630-635. [CrossRef]

109. Xu, J.; Li, H.; Liu, Y.; Huang, L.; Zhang, J.; Shi, L.; Zhang, D. In situ fabrication of porous $\mathrm{MnCo}_{x} \mathrm{O}_{y}$ nanocubes on Ti mesh as high performance monolith de-NO ${ }_{x}$ catalysts. RSC Adv. 2017, 7, 36319-36325. [CrossRef]

110. Xu, H.; Zhang, Q.; Qiu, C.; Lin, T.; Gong, M.; Chen, Y. Tungsten modified $\mathrm{MnO}_{x}-\mathrm{CeO}_{2} / \mathrm{ZrO}_{2}$ monolith catalysts for selective catalytic reduction of $\mathrm{NO}_{x}$ with ammonia. Chem. Eng. Sci. 2012, 76, 120-128. [CrossRef]

(C) 2018 by the authors. Licensee MDPI, Basel, Switzerland. This article is an open access article distributed under the terms and conditions of the Creative Commons Attribution (CC BY) license (http:/ / creativecommons.org/licenses/by/4.0/). 